\title{
A systematic review of STEM education research in the GCC countries: trends, gaps and barriers
}

\author{
Fatma Kayan-Fadlelmula ${ }^{*}$ (D), Abdellatif Sellami ${ }^{2}$, Nada Abdelkader ${ }^{3}$ and Salman Umer ${ }^{2}$
}

\begin{abstract}
Abundant research conducted in many countries has underlined the critical role of Science, Technology, Engineering, and Mathematics (STEM) in developing human capital in fields important to a nation's global competiveness and prosperity. In the Gulf Cooperation Council (GCC) States, recent long-term policy plans emphasize the ever-increasing need of transition to a knowledge-based economy and preparing highly qualified nationals with credentials in STEM fields to meet the current and future needs of the labor market. Yet, despite multiple educational reforms and substantial resources, national and international indicators of student performance still demonstrate insignificant improvement in GCC students' achievement in STEM subjects. Demonstrably, the GCC youth still lack interest in STEM careers and represent low enrollment rates in STEM fields. This paper presents the results of a systematic review conducted on STEM education research in GCC countries. The review seeks to contribute to the body of the existing STEM literature, explore the factors influencing student participation in STEM, and identify the gaps in STEM education research in those countries.
\end{abstract}

Keywords: STEM, STEM education research, STEM barriers, TIMSS, PISA, GCC, Systematic review

\section{Introduction}

Over the years, great emphasis has been placed on STEM as a field study that is key to gaining a competitive edge on the world stage, resulting in a global shift in educational paradigms highlighting the importance of STEM. One of the drivers for this shift may be accounted for in terms STEM's potential to enable students to be critical thinkers capable of finding solutions to the ills modern societies face (Robinson, 2016). Thus, STEM education has a unique role to play because of its ability to solve real-world problems in the areas of health, energy and environment (Durik et al., 2015; Martín-Páez et al., 2019; Struyf et al., 2019).

\footnotetext{
*Correspondence: fkayan@qu.edu.qa

${ }^{1}$ Core Curriculum Program, Deanship of General Studies, Qatar University, P.O. Box 2713, Doha, Qatar

Full list of author information is available at the end of the article
}

Across the world, a priority for educational systems is to prepare the youth for the workplace in the midst of a dynamic, vibrant and challenging environment characterized by sophisticated technologies, a globalized and competitive economy, and social diversity. Graduates are expected to possess the critical skills required to compete in competitive global labor markets, including academic, technical, and soft skills (Breiner et al., 2012; Deming \& Noray, 2020; McGunagle \& Zizka, 2020). Whereas STEM education is essential for preparing graduates for the job market, it is also a primordial driver of human capacity building (Miller-Idriss \& Hanauer, 2019).

The ongoing calls for a mode of teaching that integrates STEM subjects in the school curriculum reflect the importance of STEM in education (Holmlund et al., 2018; Li, 2019; Morrison \& Bartlett, 2009). In the United States, for example, educational reforms emphasize the need to develop students' complex technology and engineering skills required to participate in a knowledge-based 
economy (Börner et al., 2018; Van Laar et al., 2017; Wang et al., 2011). In the GCC, local governments have invested significant finances in their educational systems to address social, economic political and security challenges. Prominent among these challenges are problems associated with falling oil-prices and the lack of qualified national professionals (Wiseman et al., 2016). To develop a sustainable knowledge-based economy and produce a skilled workforce capable of meeting the demands of modern society, the GCC States have identified longterm goals and introduced various educational reforms placing great emphasis on STEM (Fasano \& Goyal, 2004; Hvidt, 2013; Ramirez et al., 2006).

Qatar and the United Arab Emirates (UAE), as in the rest of the GCC, have attained progress along different developmental stages of education, in part due to the intense borrowing of best educational practices from around the world (Powell, 2014). Over the past two decades, students from Qatar and the UAE have participated in international assessments to achieve high standards (Morgan, 2018). Participation in these assessments helps countries to benefit from expert advice in order to improve students' performance (Elliott et al., 2019; Nóvoa \& Yariv-Mashal, 2003). Countries also selectively borrow from reference societies that score high on international assessments (e.g., Singapore and Finland) to ameliorate their education systems (Mohamed \& Morris, 2021; Steiner-Khamsi, 2003).

This study aims to analyze scholarly papers that have examined STEM education in the GCC. The review seeks to examine barriers to STEM participation and identify gaps and issues in STEM education research across the GCC countries.

The main research problems that guide this review are as follows:

1. What are the general trends in STEM education research across the six GCC countries?

2. What are the factors likely to shape participation in STEM education across the GCC countries?

3. What are the main gaps and problems characterizing STEM education research in the GCC countries?

The present study provides a systematic review of STEM in the GCC, a topic that has not been addressed before. In the face of the declining aspirations of GCC youth in STEM fields (Said, 2016) and their underachievement in international assessments (Morgan, 2018), such as Trends in International Mathematics and Science Study (TIMSS) and Programme for International Student Assessment (PISA), STEM education for sustainable development is increasingly gaining momentum within the GCC countries. Studies conducted in this field are key to educational policy in each GCC state, especially in light of these countries' strategic plans and visions to build a national capacity possessing the skills that are critical to developing a sustainable knowledge-based economy (Hvidt, 2013).

From a broader perspective, the need for a creative, innovative and highly skilled work force is on the rise across the world (Birch, 2017). Given STEM disciplines permeate many facets of modern life and because of the limitless possibilities they create (Malecki \& Ewers, 2007), STEM professions stand out as critical to a nation's sustainable growth and prosperity (Greenwood et al., 2011). In an attempt to identify the challenges operating against recruiting and retaining students in STEM disciplines, this study highlights the key barriers that should be addressed as a priority. Therefore, the findings can inform public policy and professional practice in areas related to STEM education.

The motivation behind this present study stemmed from the realization that while the official and public discourse in the GCC region stresses the importance of STEM, GCC student performance in international tests has generally been meager, with slight improvements in recent years (Mullis et al., 2012, 2016, 2020; OECD, 2014, 2016, 2018). Because STEM is key to the transition to a knowledge society and to building national capacity in the skills that are critical to the twenty-first century, this study is a modest attempt to contribute to research that investigates STEM in the GCC countries.

Interest in STEM-related fields of study and professions has garnered attention from researchers in the West and elsewhere (Bybee, 2018; English, 2017; Holmlund et al., 2018; Lee et al., 2019; NASEM, 2018). However, this subject is still clearly under-studied in the Arab world. Much less is known about the topic in the context of the GCC area. By providing a review of research conducted on STEM education in the GCC countries, the paper offers an alternative non-Western perspective on STEM that will be of interest to the international readership. Focusing on the Arabian Gulf states provides insights that can help in understanding the general trends characterizing STEM education in these countries and in deciphering whether the factors known to shape participation in STEM education in previous studies implemented outside the region-especially in the U.S. and Western Europe-apply in the GCC area. Similarly, such insights may also shed light on the barriers likely to impede STEM education in the Gulf States.

This article is organized as follows: the first section provides some background information about the performance of GCC students in international assessments such as PISA and TIMSS. The following section focuses on the available literature on the barriers that 


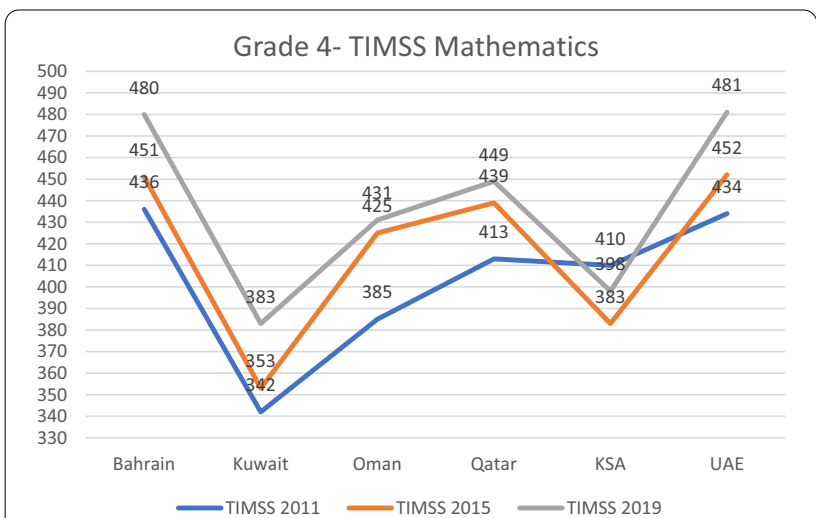

Fig. 1 Grade 4 TIMSS Mathematics performance in GCC States

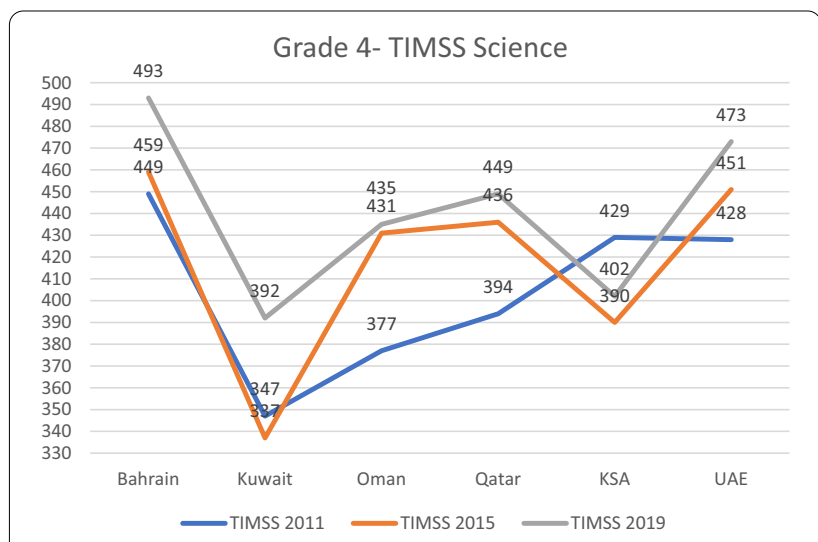

Fig. 2 Grade 4TIMSS Science performance in GCC States hinder students' participation in STEM fields of study, and examines the main factors that shape students' interest, learning and achievement in STEM. The subsequent section descries the methodology used in the present review, looking at the key selection criteria and the data extraction techniques. This is followed by a presentation of the study's results and a discussion of the main findings from this systematic review. The paper concludes with some recommendations for future research.

\section{GCC student achievement in international assessments}

TIMSS and PISA are large-scale international assessments coordinated by the Organisation for Economic Co-Operation and Development (OECD) and the International Association for the Evaluation of Educational Achievement (IES). The purpose of these assessments is to measure a country's educational achievement against international standards as well as recommend potential improvements. In particular, both tests measure mathematics and science achievement. Whereas TIMSS is conducted every four years, targeting fourth and eighth graders (Mullis et al., 2012), PISA is conducted every 3 years, targeting 15-year-old students (OECD, 2014).

With regard to TIMSS, all six GCC countries took part in TIMSS in 2011, 2015 and 2019, with figures illustrating students' performance in mathematics and science for each country over the last three cycles (Martin et al., 2012, 2016; Mullis et al., 2012, 2016, 2020). In particular, Figs. 1 and 2 demonstrate the scores for fourth graders while Figs. 3 and 4 present the scores for eighth graders. Based on the results, it is evident that grade 4 and grade 8 students' TIMSS performance in mathematics and science increased from 2011 to 2019. Consistently, the UAE and Bahrain appear to be the top performers among the GCC countries and KSA and Kuwait the lowest. All six countries rank under the center point score of 500, closer to low international benchmark of 400 .

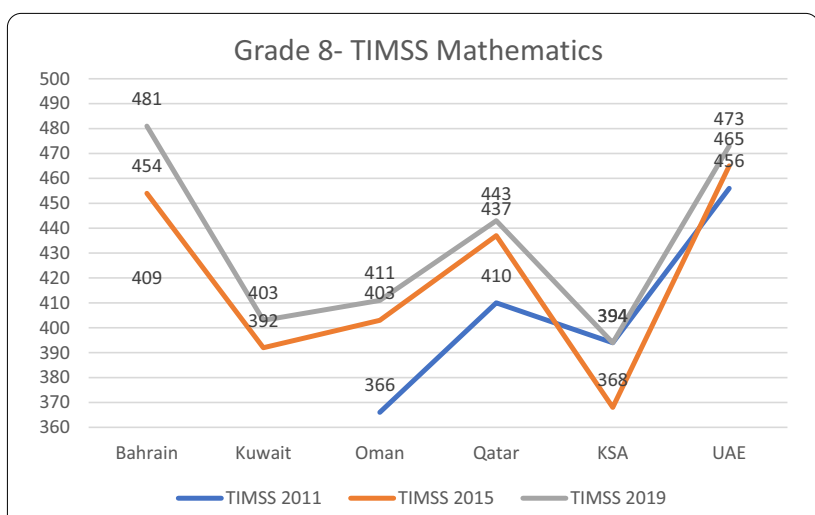

Fig. 3 Grade 8 TIMSS Mathematics performance in GCC

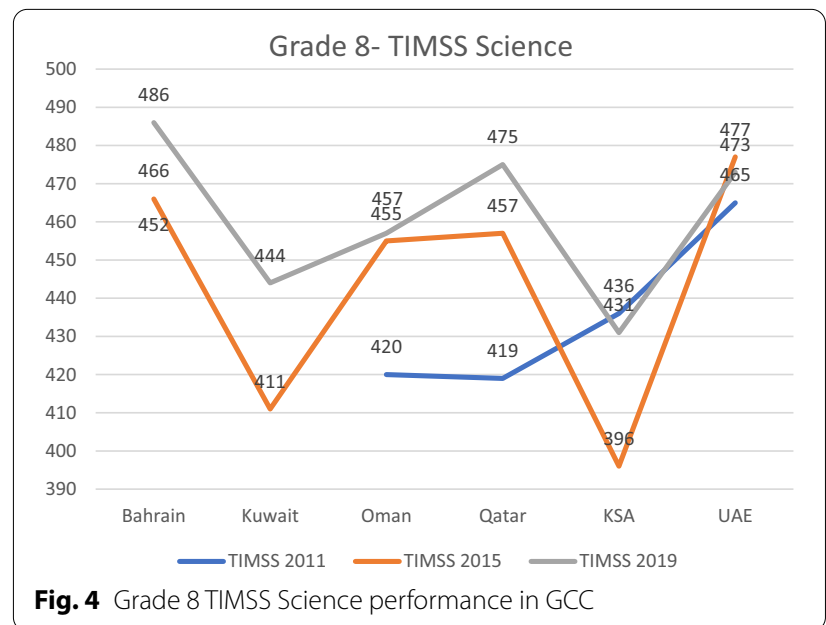

As with PISA, only Qatar and the UAE have consistently participated in PISA for the last three cycles. Figures 5 and 6 illustrate the two countries' achievement scores in mathematics and science for 2012, 2015 and 


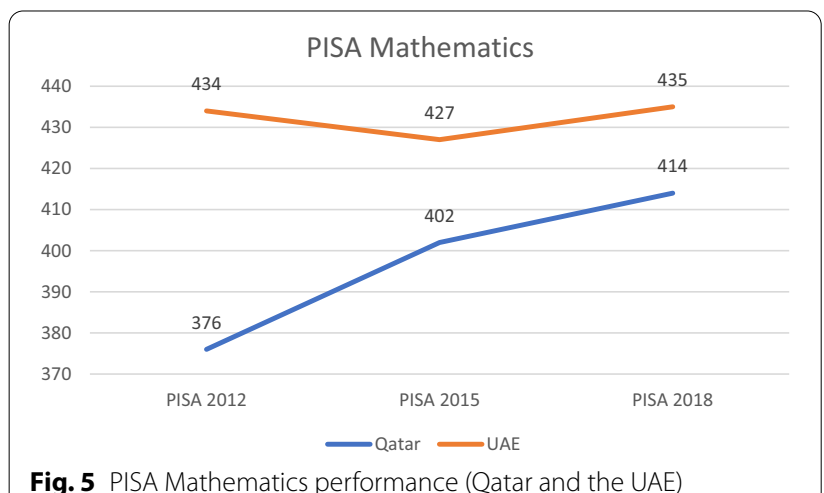

Fig. 5 PISA Mathematics performance (Qatar and the UAE)

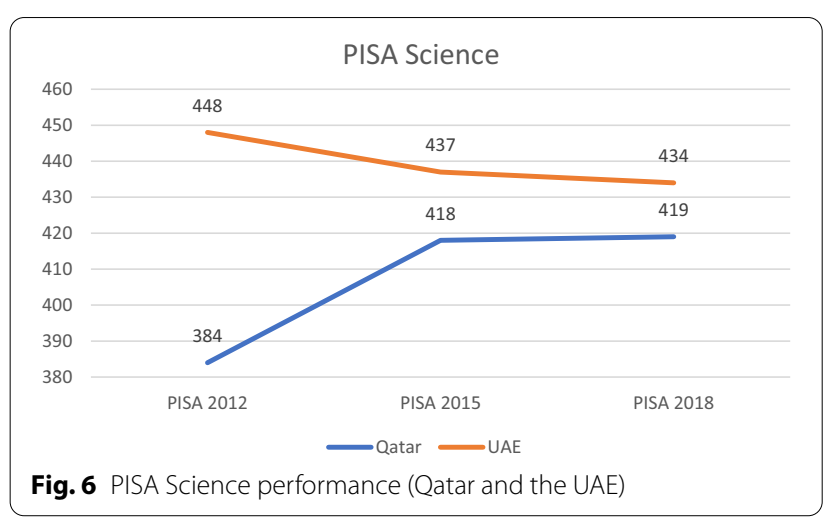

2018 (OECD, ). As was the case with TIMSS, the performance of Qatar and the UAE in PISA has improved over the years. While the UAE has outperformed Qatar in all stages for both mathematics and science subjects, both countries are still below the center point score of 500 , lagging behind the average of other developing countries.

\section{Scholarship on barriers to STEM education}

Extant research on students' interest and persistence in STEM-related education and careers has often drawn on two well-known theories. The first model is Eccles's Expectancy-Value Theory (EVT) (Eccles, 1983, 2009), provides one of the most comprehensive theoretical frameworks for studying the intricate factors underlying individual and gender differences in STEM educational and career choice. According to the theory, achievementrelated choice is governed by a range of factors divided into two categories: expectancy for success and subjective task value (Eccles, 2009; Eccles-Parsons et al., 1982). Expectancy of success, which refers to the individual's expectation that he/she can succeed at a challenging task, develops over childhood and adolescence and is shaped by factors such as self-concept of abilities, gender stereotypes, socio-cultural influences, and previous achievement-related experiences. Several studies suggest that self-efficacy plays a central role in informing career considerations and decisions (Su et al., 2009).

The second model, the Social Cognitive Career Theory (SCCT), was proposed by Lent et al. (1994). SCCT emphasizes the interrelationships between individual, environmental, and behavioral variables, which can predict one's interest and choice of a career (Brown \& Lent, 1996). SCCT relies on key factors such as self-efficacy, outcome expectations, interests, environmental supports and barriers, and choice actions (Lent et al., 2002). According to SCCT's model of interest and choice, selfefficacy promotes favorable outcome expectations. Students tend to develop interest in academic subjects when they possess a strong self-efficacy and subsequently positive outcome expectations. The model also takes into consideration gender, race and socio-economic background as well as learning experience (Lent et al., 2002).

For the purposes of this study and building on Van den Hurk et al. (2019) model (Fig. 7), we focus on three broad types of factors: (1) environmental factors (e.g., the social context and social environment); (2) school-level factors (e.g., instruction, teachers, and pedagogy); and (3) student-level factors (e.g., students' attitudes, motivation and aptitude).

\section{Environmental factors}

Presently, educational policy ranks high on the GCC's political agendas, emphasizing the need to attract, retain and prepare students in STEM fields of study and profession (Said, 2016). Herein lies the leading role education can play in supplying STEM skills and talents in the different GCC countries as they transition to knowledge societies. Thus, policy-makers have embarked on ambitious projects to improve students' skills and abilities in STEM (Murphy et al., 2019). Exacerbating the lack of STEM-related skills is the zeal for public sector employment among GCC citizens (Wiseman et al., 2016). At present, preference for public sector employment remains a magnet attracting job-seeking GCC youth, to the detriment of the private sector's attractiveness (Abdel-Ahad \& Tzannatos, 2016). In the face of this highly segmented labor market in the GCC countries, combinations of attitudes, knowledge and skills in STEM are identified as critical for building the human capital necessary for competitive knowledge economies (Wiseman et al., 2016). To this end, STEM education has gained increasing importance in these countries' policy-making, with specific emphasis placed on the urgency of enhancing students' entrance into, persistence in and completion of degrees in STEM fields.

Viewed as important examples of environmental factors, cultural and contextual factors have been identified 


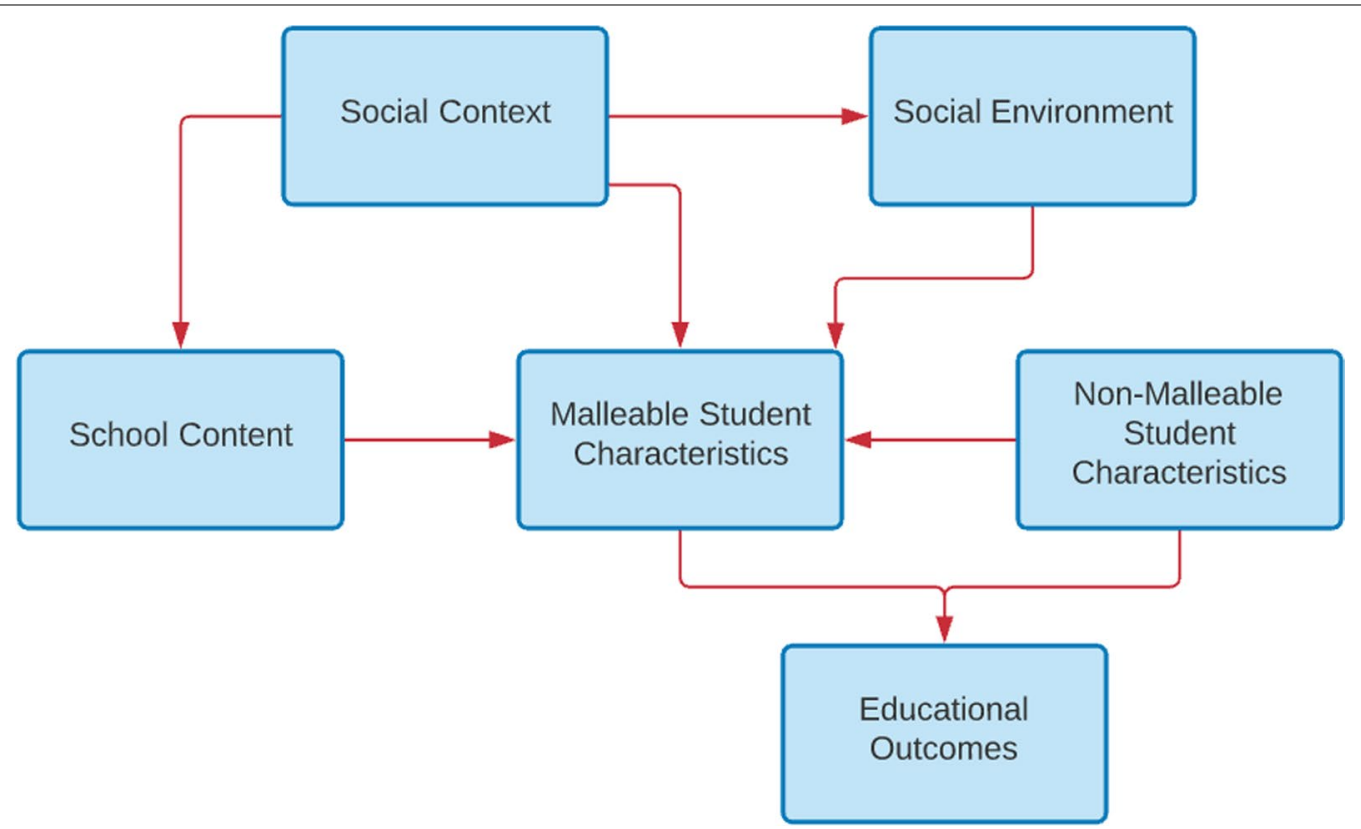

Fig. 7 Theoretical model of factors affecting STEM persistence (adapted from Van den Hurk et al., (2019)

in the extant literature as influences that shape students' STEM-related interests, expectations and aspirations. Cultural influences encompass factors such as society's perceptions of STEM, gender stereotyping, and role modeling, all of which can impact students' pursuit of education and careers in STEM domains. For example, while STEM-related presently constitute some of the best paying and the fastest growing in the job market (Preston \& Whitehouse, 2004), this is an area that is still failing to attract GCC nationals, especially within the private sector.

In the GCC and the larger Arab world, government jobs have traditionally been very appealing and highly sought after, compared to those in the private sector (Momani, 2017). As Gatti et al. (2013) point out, "while some of the most coveted jobs are in the public sector and provide high individual returns, these are not necessarily associated with the highest productivity for society" (p. xxvii). This stands in sharp contradiction to the teachings of Islam, the official and predominant religion of GCC nations. Reporting work by Al-Heeti and Brock (1997), Wiseman et al., (2016) argue, "Ironically, this perception contradicts traditional Islamic principles" (p. 365) which are "strongly opposed to this negative attitude toward vocational and manual work" (p.374).

Cultural stereotypes also shape how STEM is perceived in society. Arguably, they play a significant role in reinforcing the claim that women are less welcome in the field, and these stereotypes affect female participation in STEM domains (Pasha-Zaidi \& Afari, 2016).
Indeed, some claim that gender stereotypes can lower girls' STEM aspirations (Bradley, 2000). For example, Keeves and Kotte (1992) examined students from different countries and found that although females a more interested in school, males consistently held more favorable attitudes toward science than females did. Another study by Badri et al. (2016) revealed that girls select science-related careers that offer opportunities to address socio-economic and environmental issues. Interestingly, however, other research carried out in Qatar by Said et al. (2016) explored the possible impact of culture on students' interest in STEM in Qatar and found no significant gender-related differences in attitudes toward science among Arab students.

Contextual influences encompass factors such as role models and the family. Female students encounter contextual barriers in their pursuit of future STEM degrees and careers. One such barrier that is especially pertinent in the GCC and the Arab world in general, is the shortage of female role models to look up to, such as highly successful educated mothers and female scientists. Indeed, successful role models who set examples and provide a motivational drive for an individual in a specific field of interest is an important theme that is recurrent in STEM scholarship (Herrmann et al., 2016). Other work by Drury et al. (2011) and Stout et al. (2011) suggests that female STEM expert role models promote women's selfconcept and enhance positive attitudes toward STEM.

Other contextual influences, both inside and outside school, have been found to shape decisions regarding 
STEM fields of study and careers. For example, research by Herbert and Stipek (2005) and Simpkins and DavisKean (2005) reveals that girls with an interest in STEM receive less encouragement within the home and inside the classroom compared to boys. Other evidence from Burke and Mattis's (2007) study shows that limited opportunities for STEM extracurricular activities led to 6th-8th grade girls opting out of science and mathematics courses.

The role of the family is also identified as an important influence in women's educational choices of STEM fields (Carter, 1989; Phipps, 2002). Compared to men, women are more likely to enter engineering owing to family encouragement than to their own intrinsic interest (Aswad et al., 2011). By contrast, in family-based Arab societies such as Qatar, parental influence on educational choice is expected to be even more pronounced (Sellami, 2019). Aswad et al., (2011), for instance, examined the factors that influence Emirati women's decisions regarding their degree program and their attitudes towards science, technology and engineering and confirmed the key role played by the family.

\section{School-level factors}

Of the school-related factors affecting student participation in STEM, the curriculum stands as the most prominent. As Asghar et al. (2012) suggest, the curriculum needs to be developmentally appropriate and firmly connected to standards. Research has shown that the success of STEM initiatives can be attained when a quality curriculum is implemented (Asghar et al., 2012). More recently, Park et al. (2017) note that teachers' readiness level to teach STEM increases with their teaching experience. Several studies emphasize that teachers' positive attitudes toward STEM increase students' interest in STEM credentials and careers (Krapp \& Prenzel, 2011). Research also shows that textbooks are a primary source of knowledge for students and a major resource for teachers (Reys et al., 2004). Researchers argue that different textbooks can affect students' learning outcomes (Bierhoff, 1996). As Freeman et al. (2014) point out, the use of interactive textbooks improves students' academic achievement considerably.

In addition, research shows that negative school experiences may deter students from pursuing STEM degrees and career aspirations (Aschbacher et al., 2010). For instance, research by Aschbacher et al. (2010) demonstrates that students' positive school experiences contribute to enjoyment of science and can inspire their interest in and pursuit of science subjects. Similarly, Carlone and Johnson (2007) have found that positive experiences of science help students build competence and self-confidence and thus contribute to persistence in science and career aspirations. Recognition of one's competence and abilities by others, especially teachers and parents, can also bolster self-concept and self-efficacy in science (Aschbacher et al., 2010). In turn, positive self-concept and self-efficacy in science can influence aspirations (Bandura et al., 2001) and students' educational choices, which are important pathways to attaining those aspirations (Rodeiro, 2007).

Science and mathematics education can happen in diverse contexts, not only through pedagogical interventions in school but also in casual, spontaneous, nonstructured places in informal settings (Kim \& Dopico, 2016). However, it has been shown that students' participation in informal science learning and how much they gain from it are not only driven by their own interests in those activities, but are also fundamentally shaped by physical (activity location), economic (associated costs), social (support from important family members), and cultural factors, in addition to their science capital (DeWitt \& Archer 2017). The combination of these factors can either open up or shut down students' access to and participation in science education in informal settings. The conclusions derived from the current review indicate the impact of social and cultural factors in shaping GCC students' interest or disinterest in STEM.

\section{Student-level factors}

Numerous student- or individual-level factors shape students' interest and achievement in STEM. In particular, the literature shows that students' interests (Osborne et al., 2003), attitudes and self-efficacy beliefs (Schreiner \& Sjøberg, 2004) affect their academic achievement (Jones et al., 2000) and their educational and career choices (Badri et al., 2016). Future career aspiration is another factor influencing student engagement in STEM education (Jenkins \& Nelson, 2005). Evidence shows that ideas of future career aspirations begin to take shape in the early years of secondary school (Badri et al., 2016).

The gender gap in STEM educational and occupational expectations has also been the subject of extensive research (Han, 2016). There is evidence that suggests that boys are more likely to express interest in STEM fields while girls tend to be more interested in pursuing non-STEM fields (Su et al., 2009). Other research by Chachashvili-Bolotin et al. (2016) shows that girls' enrollment in STEM fields does not necessarily translate into their choice of one of these fields as a career path.

Students' motivation to learn has also been identified as a key determinant of their interest in pursuing STEM (León et al., 2015). Alongside motivation, research shows strong linkages between students' early career aspirations and their eventual entrance into a STEM career (Blustein et al., 2013). According to Tai et al. (2006), 
young adolescents expecting to have a career in science were more likely to graduate from college with a science degree. Moreover, Wiseman et al., (2016) have identified nationality as an important determinant of participation in STEM studies and professions. The researchers report that whereas GCC nationals do not emphasize STEM education as an avenue for future employment, expatriate youth do.

Arguably, factors not related to education, including family influence and nepotism, often play a key role in securing a job in the GCC region. For instance, nepotism pervades different arenas of GCC societies, including landing or securing a job, accessing public services, marriage arrangements (Kropf \& Newbury-Smith, 2016). According to the World Bank (2008), public sector job trends show that nepotism, personal connections, and favoritism supersede individual merits and achievements in hiring and job promotions:

Studies show that recruitment into the public sector often bypasses official channels and thus any vetting of qualifications. According to cross-national indices, GCC civil services have higher levels of favoritism in recruitment and advancement than comparators in the OECD and MENA region (World Bank, 2018, p. 46).

\section{Methods}

To explicitly and systematically analyze published research on STEM education in the GCC, a systematic review was conducted. As Gough et al. (2012) state, a systematic review is a transparent and replicable method of literature review that answers research questions based on accountable methods with explicit criteria that include or exclude existing studies. Data are derived from the reports of published studies, systematically synthesizing existing knowledge on a particular issue and spotting gaps (Møller \& Myles, 2016). To ensure credibility, consistency and transparency, this systematic review was conducted in concurrence with the Preferred Reporting Items for Systematic Reviews and Meta-Analyses (PRISMA) guidelines and the four-phase flow diagram (Liberati et al., 2009). In particular, the PRISMA consists of a detailed checklist addressing all the major sections of a systematic review, providing an evidence-based foundation for transparency in identifying, selecting, appraising, and synthesizing the studies being reviewed (Moher et al., 2009).

\section{Eligibility criteria}

Abundant research has treated STEM worldwide, focusing either on individual STEM disciplines (e.g., science, technology, engineering or mathematics) or interdisciplinary/cross-disciplinary combinations of different STEM disciplines (e.g., "mathematics and science" or "science and engineering"). Naturally, this causes substantial challenges for researchers examining STEM education, requiring a "careful thought and clearly specified scope to tackle the complexity" (Li et al., 2020, p. 2). To address this challenge, as was done in prior STEM reviews (Brown, 2012; Li et al., 2020; Mizell \& Brown, 2016), this study examines only papers that have the acronym STEM covered within them, including the title, the abstract and the keywords, hence self-identifying the paper as connected to STEM fields.

Harden and Gough (2012) write that in appraising the quality and relevance of studies the review needs to "ensure that only the most appropriate, trustworthy and relevant studies are used to develop the conclusions" (p. 154). Peer reviewed scholarly articles are credited as the most important outlets for research exchange (Lin et al., 2019, 2020; Xu et al., 2019). Due to the rigorous process under which they are published in academia (Nicholas et al., 2015), the eligible studies in this review consist of peer-reviewed scholarly articles, written in English, with a title, abstract or keywords.

\section{Information sources}

In December 2020, Qatar University library website was used to access the information sources required for our search. When the electronic databases were sorted according to subjects, two possible subject categories were identified as relevant to STEM education: (a) Education (11 databases) and (b) Engineering and Computer Science (30 databases). After comparing electronic databases lists that appeared under both subject categories, three databases were found to be in both categories, as Academic Search Ultimate (Ebsco), Pro Quest Central, and Taylor and Francis Online. Hence, the search was conducted using these three databases, which are large, international, scholarly and multidisciplinary databases.

\section{Search}

In the search, Boolean operators were applied within each database, using specific search terms and limiters, as described in Table 1. In particular, the search terms were "STEM education" and the "GCC" and any of the individual GCC countries together with their acronyms. The results were restricted to peer-reviewed scholarly papers written in English. No restriction was applied on the publication year. The search generated 13 results for Academic Search Ultimate (Ebsco), 28 results for Pro Quest Central, and 27 results for Taylor and Francis Online, yielding a total of 68 results. 
Table 1 Results of initial search

\begin{tabular}{|c|c|c|c|}
\hline Search terms* & Search limiters & Databases & Hits \\
\hline \multirow{3}{*}{$\begin{array}{l}\text { ("STEM education") AND ("GCC" OR "Kuwait" OR "Bahrain" OR "Qatar" OR } \\
\text { "United Arab Emirates" OR "UAE" OR "Saudi Arabia" OR "KSA" OR"Oman") }\end{array}$} & Peer reviewed & Academic Search Ultimate (Ebsco) & 13 \\
\hline & $\begin{array}{l}\text { English } \\
\text { Peer reviewed } \\
\text { Scholarly journals } \\
\text { Extra limiters } \\
\text { Subject—STEM education } \\
\text { Location—only GCC countries }\end{array}$ & Pro Quest Central & 28 \\
\hline & Subject_education & Taylor and Francis Online & 27 \\
\hline Total & & & 68 \\
\hline
\end{tabular}

*Searches included all fields, such as titles, abstracts, and keywords

\section{Study selection}

The flow of the study selection process, including identification, screening, eligibility, and included studies, is illustrated in Fig. 8. Briefly, using our search terms (see Table 1), the search based on the three selected databases (Academic Search Ultimate, Pro Quest Central and Taylor and Francis Online) generated 68 papers. After screening for duplicates, 8 papers were eliminated. After applying the inclusion criteria, 5 papers were excluded because they were not scholar papers, 23 were rejected for their irrelevance to STEM, and 14 were dropped for not being relevant to GCC. In total, 18 papers were retained for the systematic review; these papers are marked with an asterisk in the references list and are also listed in "Appendix A".

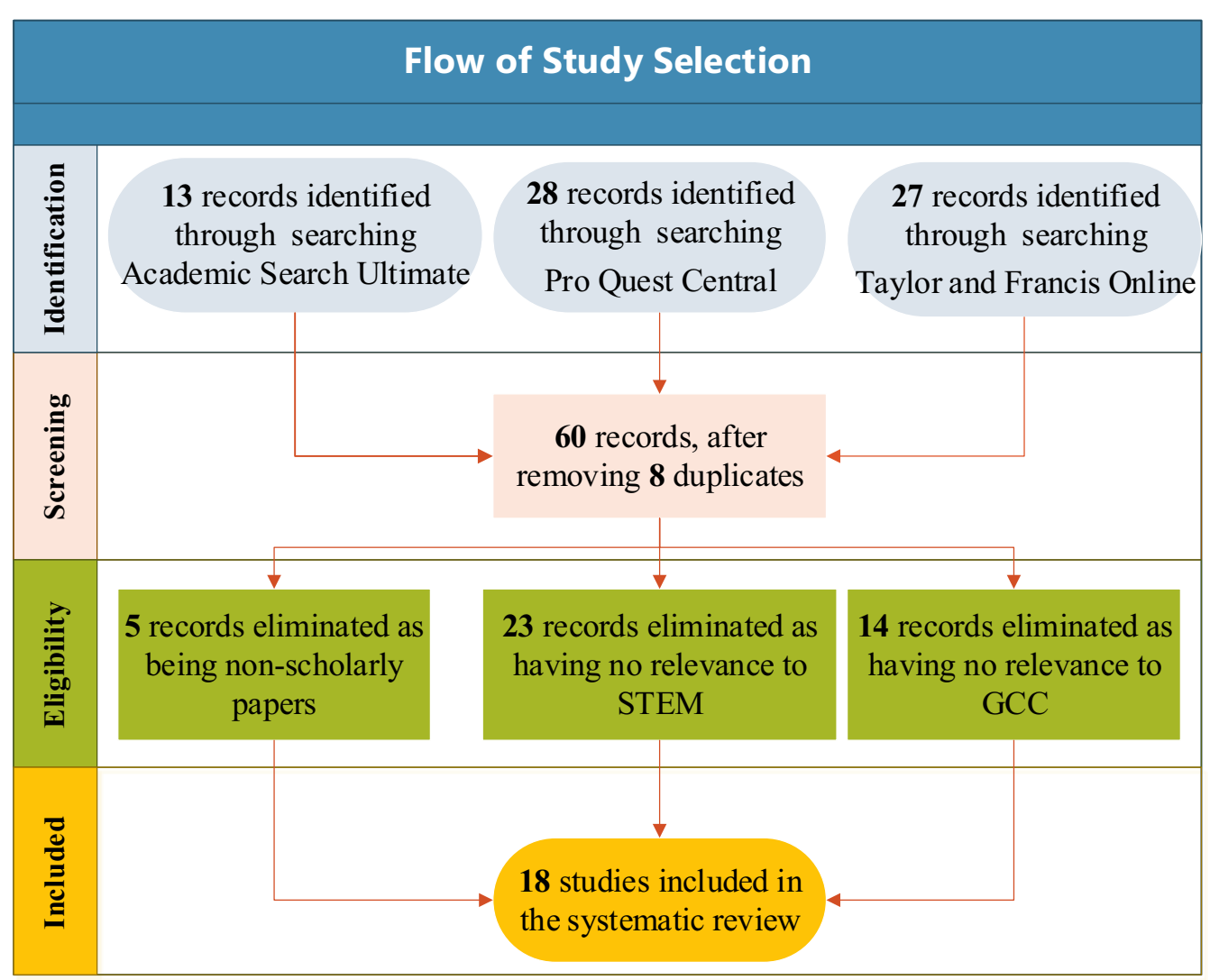

Fig. 8 Flow of the study selection 


\section{Data extraction process}

Individually, the researchers reviewed and extracted information from the selected papers in a spread excel sheet. The data extracted from the papers comprised information about the authors, year of publication, research country, participants, education level, research methods, thematic focus, as well as the gaps and problems related to STEM research in the GCC. Prior to extracting the data, the research team established a coding protocol, which made it easy to analyze the data. The variables for which data were sought and the codes are listed in Table 2 below.

The coding for the country under study included all the GCC countries individually (Bahrain, Kuwait, Oman, Qatar, KSA, and UAE) and the GCC broadly. Regarding participants, the codes included K-12 students, undergraduate students, graduate students, K-12 teachers, faculty members, and parents. For the level of education, codes were generated for higher education, secondary education, and primary education. Here, primary education refers to primary (grades 1-6) and preparatory (grades 7-9) levels, whereas secondary education refers to grades 10-12.

With respect to the research methods, the codes included qualitative studies (e.g., case studies, historical studies, grounded studies), quantitative studies (e.g., surveys, experimental and correlational studies), mixed studies (e.g., explanatory, exploratory, multiphase), and conceptual studies (e.g., systematic reviews, reflection papers, opinion papers). Regarding the thematic focus, the theoretical model described in the literature was used to set the scene for this study. Accordingly, the coding included cultural factors (stereotypes, and parental, cultural and societal beliefs), contextual (i.e., environmental) factors (e.g., educational policy), school-level factors (e.g., the curriculum, assessment, and teachers) and studentlevel factors (e.g., gender, socio-economic status, self-efficacy, motivation, aspirations, attitude, and achievement).

\section{Risk of bias}

To guard against selection bias, the researchers individually used the same search terms, limiters and databases, and reviewed the included and excluded papers for relevance. A review of titles, abstracts and key words allowed checking for conceptual and empirical alignment. Each researcher confirmed that all the papers that were retained met the eligibility criteria. However, the research team was aware that limitations with the search terms and the selected databases could result in an incomplete set of relevant papers, as explained in the limitations section.

Interrater reliability was calculated using a percent agreement metric (McHugh, 2012). Before extracting data from the selected papers, the researchers established a coding protocol for each variable (see Table 2). The papers were then analyzed by the researchers individually using a set of codes. An "Other" option was added for each variable where extracted data were not represented by the available codes. In this case, the researchers clearly defined what "other" stood for. Each researcher extracted 126 pieces of data from the 18 selected papers, agreeing on 116 pieces, making an agreement rate of 0.92. The disagreements were mostly related to research methods since in many of the papers the authors did not provide a clear description of the methods employed. Disagreements were reconciled among the research team easily by referring back to the full text and discussing the lack of methodological clarity or possible confusion or ambiguity. Yet, while all the selected studies were meticulously reviewed and analyzed by individual researchers with disagreements discussed and resolved, the chance of having overlooked or misinterpreted information in the reviewed articles cannot fully be ignored.

\section{Results}

Research Question 1 What are the general trends in STEM education research across the six GCC countries?

Results from our review disclose some interesting trends, which may be understood by looking at the key demographic, geographic, and methodological characteristics employed in examining STEM. In looking at the distribution of these studies according to the time of publication (Fig. 9), is it clear that research on STEM education in GCC started in early 2011, $(n=1,5.6 \%)$ with an increase in $2016(n=3,16.7 \%)$ and $2017(n=3,16.7 \%)$, reaching the highest rate in $2019(n=5,27.8 \%)$. As Fig. 9

Table 2 Data items and coding protocol

\begin{tabular}{llll}
\hline Country & Participants & Level of Education & Methods \\
\hline 1. Bahrain & 1. K-12 students & 1. Higher education & 1. Qualitative \\
2. Kuwait & 2. Undergraduate students & 2. Secondary education & 2. Quantitative \\
3. Oman & 3. Graduate students & 3. Primary education & 3. Mixed \\
4. Qatar & 4. K-12 teachers & 4. Other & 4. Conceptual \\
5. KSA & 5. Faculty members & & 5. Other \\
6. UAE & 6. Parents & & 4. Student-level factors \\
7. GCC & 7. Others & & \\
\hline
\end{tabular}



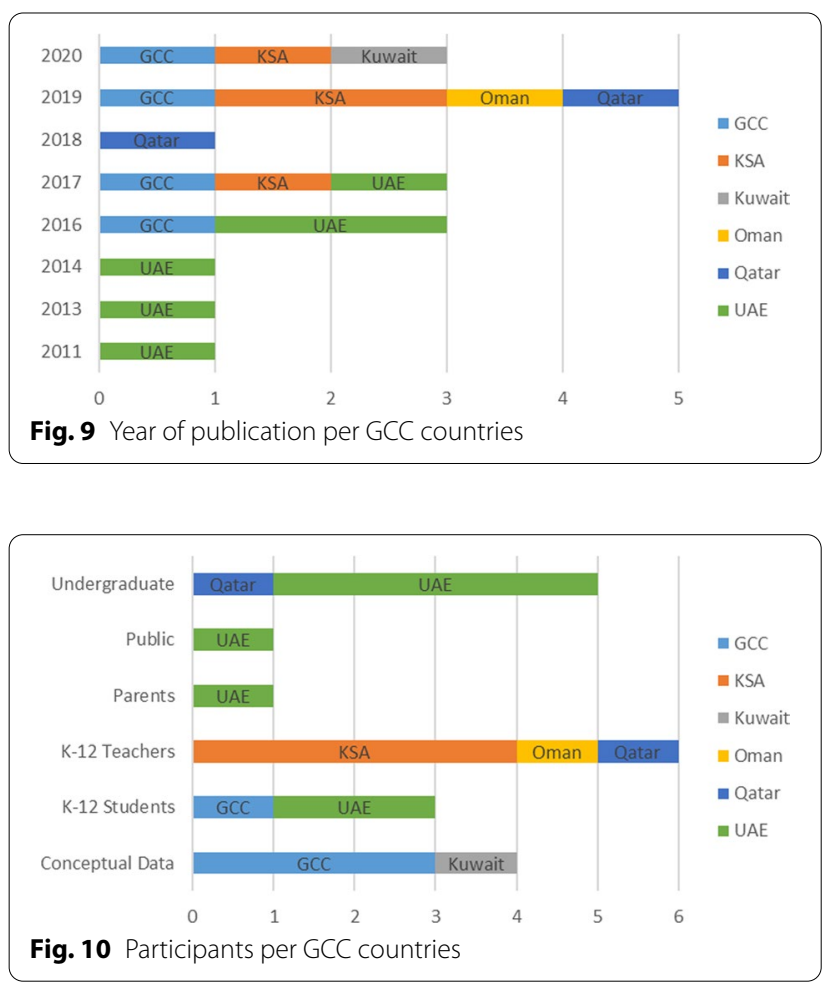

demonstrates, the $\operatorname{UAE}(n=6,33.3 \%)$ emerged as the country where research originated in the GCC region, with the earliest and largest number of published papers in 2011, 2013, 2014, 2016, and 2017, followed by research carried out in KSA $(n=4,22.2 \%)$ and the GCC in general $(n=4,22.2 \%)$. Moreover, few studies have focused on Qatar $(n=2,11.1 \%)$, Oman $(n=1,5.6 \%)$ and Kuwait $(n=1,5.6 \%)$. No paper seems to have examined STEM education research related to Bahrain in particular.

With regard to the study populations (Fig. 10), the results show a strong focus on K-12 teachers $(n=6$, $33.3 \%)$ and undergraduate students $(n=5,27.8 \%)$, whereas the least focus was on parents $(n=1,5.6 \%)$. In this respect, the KSA emerged as the country with the most research on $\mathrm{K}-12$ teachers $(n=4,66.7 \%)$. By contrast, most of the research examining $\mathrm{K}-12$ and undergraduate students was undertaken in the UAE $(n=4$, $80 \%$ of the five studies on undergraduate students; $n=2$, $66.7 \%$ of the six studies on K-12 students). In few cases, information was extracted from conceptual data such as the content of final examination (Kuwait, $n=1$ ), international examination results $(\mathrm{GCC}, n=2)$ and previous papers published in STEM (GCC, $n=1)$.

Concerning the methodology utilized in GCC STEMrelated studies, as Fig. 11 demonstrates, the results indicate that quantitative methodology is the most widely used $(n=8,44.4 \%)$, followed by qualitative $(n=4,22.2 \%)$, mixed $(n=3,16.7 \%)$, and conceptual
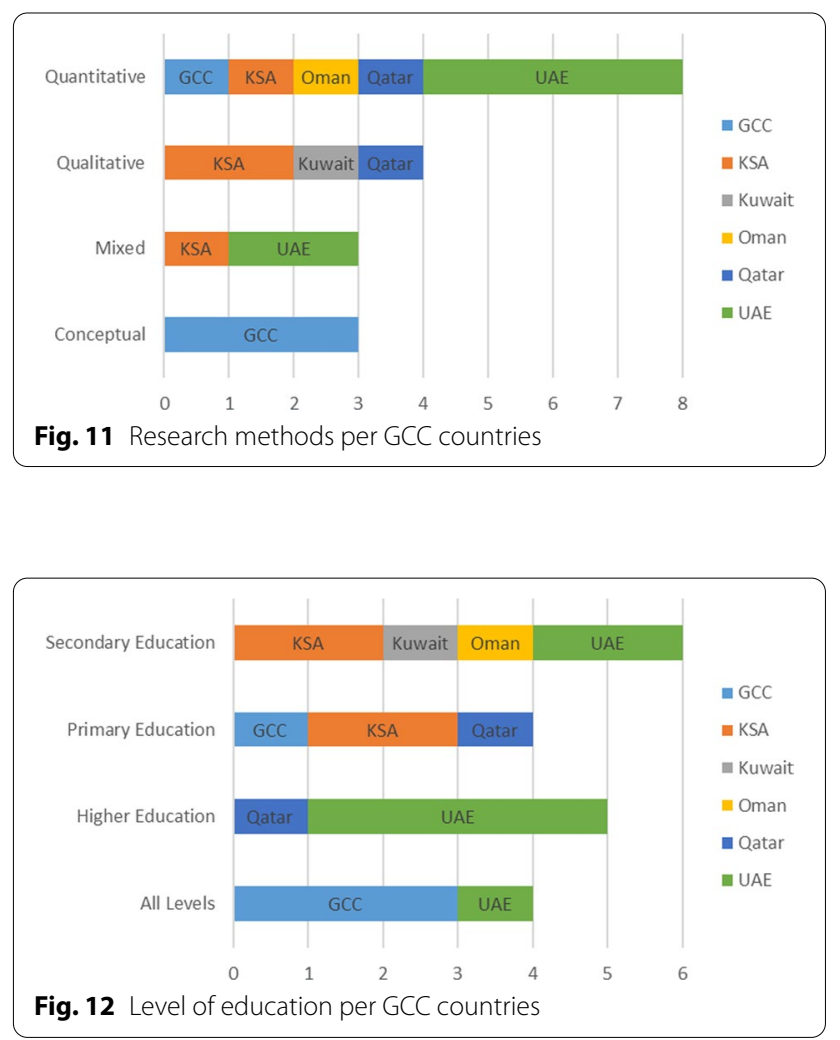

studies $(n=3,16.7 \%)$. First, quantitative studies originated in different individual GCC countries, with half of these being implemented in the UAE alone $(n=4$, $50 \%$ ); only the KSA, Kuwait and Qatar have produced research that uses qualitative methods (Fig. 11). With respect to the research that has used mixed methods, our results point to the KSA $(n=1,33.3 \%)$ and the UAE $(n=2,66.6 \%)$ as the only countries with STEM studies employing mixed methods. Equally interestingly, it seems that no research has used a conceptual framework in any one individual country, for all studies of this kind have focused on the larger GCC region $(n=3$, $100 \%)$.

With respect to the level of education examined in the existing STEM research in the GCC (Fig. 12), the results reveal a strong focus on secondary education $(n=6$, $33.3 \%)$ followed by higher education $(n=5,27.8 \%)$. By contrast, the least focus was on primary education $(n=4$, $22.2 \%)$. Looking at the country investigated, almost all the studies on higher education belong to the UAE $(n=4,80 \%)$, whereas the studies on the GCC in general were mostly related to all levels of education $(n=3$, $75 \%)$. Moreover, the studies investigating the KSA mostly focused on primary and secondary education $(n=2,50 \%$ of the four studies on primary education and $n=2,33.3 \%$ of the six studies on secondary education). 
Lastly, with regard to the affiliations of the authors and researchers that authored the selected STEMrelated studies in the GCC, the results show that of a total of 47 authors (Fig. 13), only a quarter (25.5\%) were external international researchers that examined STEM in the GCC countries [Australia $(n=4,8.5 \%)$; USA $(n=4,8.5 \%)$; Egypt $(n=2,4.2 \%)$; New Zealand $(n=1,2.1 \%)$; United Kingdom $(n=1,2.1 \%)]$. Regarding researchers from within the GCC countries, most were affiliated to national institutes, centers or higher education institutions in the UAE $(n=18,38.3 \%)$ followed by the KSA $(n=9,19.1 \%)$, Qatar $(n=4,8.5 \%)$, Kuwait $(n=2,4.26 \%)$, and Oman $(n=2,4.3 \%)$.

Research question 2 What are the factors likely to shape participation in STEM education across the GCC countries?

Looking at the factors that hinder STEM education (see Table 3), most of the studies included school-level factors $(n=10,55.6 \%)$, such as teachers' perceptions of integrated STEM education (Aldahmash et al., 2019; Elayyan \& Al-Shizawi, 2019; El-Deghaidy et al., 2017; Madani \& Forawi, 2019), STEM curriculum and pedagogy (Awwad \& Ayesh, 2013; Madani, 2020; Murphy et al., 2018), and STEM assessment (Alhashem \& Agha, 2020). Second in line of the research focus are studies on environmental factors $(n=7,38.92 \%)$, mostly related to the impact of stereotypes (Aswad et al., 2011; Forgasz et al., 2014; Pasha-Zaidi \& Afari, 2016), the role of family members (Aswad et al., 2011) and family income (Khan \& Rodrigues, 2017). These are in turn followed by cultural and societal beliefs (Wang et al., 2020), and social perceptions and prejudices towards participation in STEM education and careers (Islam, $2017,2019)$. Interestingly, student-level factors received the least attention $(n=5,27.8 \%)$, including students' nationality (Aswad et al., 2011; Wiseman et al., 2016), gender (Pasha-Zaidi \& Afari, 2016), STEM interest and

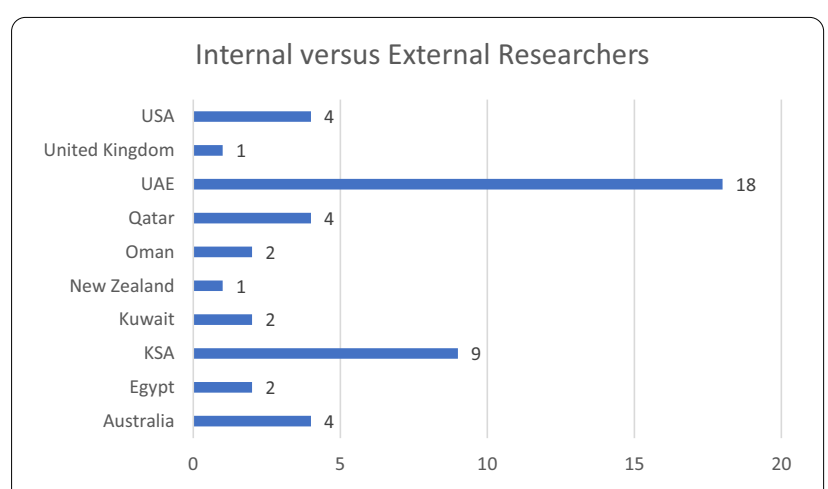

Fig. 13 Affiliations of researchers from selected papers attitudes (Al-Sheeb et al., 2019; Badri et al., 2016), as well as STEM achievement (Wiseman et al., 2016).

A close examination of research conducted on STEM across the GCC (Fig. 14) also shows a number of interesting thematic patterns. Analyzing the thematic foci of such research reveals great emphasis on school-related factors. By contrast, school and personal factors have received far less attention in STEM research. Regarding the research countries, the UAE emerges as the only individual state that has attracted research on STEM using environmental, school- and student-level characteristics whereas all other studies that have employed these factors focus on the GCC more broadly. In Qatar, studies focused on both student- and school-level factors while studies in the KSA, Kuwait and Oman examined schoollevel factors. Bahrain stands as the only state where studies investigating these factors are still lacking.

Research question 3 What are the main gaps and problems characterizing STEM education research in the GCC countries?

The reviewed STEM papers reveal a number of gaps. The first is related to STEM instruction and teacher development programs. The line of research addressing these two areas stresses that such programs should be conducted for longer time periods and be focused on training science and mathematics teachers to teach integrated STEM subjects (Aldahmash et al., 2019). The programs should also be redesigned, restructured and coupled with training and implementation practices (Madani \& Forawi, 2019). It is also suggested that workshops for training teachers should be implemented to formulate classroom questions that address real-life problem settings (Elayyan \& Al-Shizawi, 2019).

Because outdated teaching methods and non-qualified teachers/faculty undermine the quality of education (Wang et al., 2020), the literature recommends adding engineering design steps to the science curricula (Elayyan \& Al-Shizawi, 2019). There seems to be a need to rethink the process of student teaching and assessment using science concepts rather than limiting instruction to the transmission of information from textbooks (Alhashem \& Agha, 2020). In addition, enhancing dialogue between teachers of different STEM subjects is key to establishing a STEM culture, as Madani (2020) notes.

Another gap in the papers included in the present review is the limited consensus on the scope and direction of gender differences to do with performance in mathematics, and gender bias and student evaluations in higher education (Forgasz et al., 2014; Pasha-Zaidi \& Afari, 2016). Besides, empirical research investigating the career aspirations and expectations of national GCC youth is scanty. Similarly, there is no published research that looks at ICT-based instruction and/or the STEM 
Table 3 Detailed analysis of thematic focus across the STEM studies

\begin{tabular}{lll}
\hline Authors & Thematic Focus & Scope \\
\hline Aldahmash et al., (2019) & School-level factors & $\begin{array}{l}\text { Teachers' perceptions about inte } \\
\text { grated STEM pedagogies }\end{array}$
\end{tabular}

El-Deghaidy et al., (2017) School-level factors

Elayyan and Al-Shizawi, (2019) School-level factors

Madani and Forawi, (2019) School-level factors

Awwad and Ayesh, (2013)

Madani, (2020)

Murphy et al., (2018)

Alhashem \& Agha, 2020

Aswad et al., (2011)

Forgasz et al., (2014)

Pasha-Zaidi and Afari, (2016)
School-level factors

School-level factors

School-level factors

School-level factors

Environmental factors + student-level Impact of stereotypes and family factors

Environmental factors

Impact of stereotypes

Environmental factors, student-level Impact of gender disparity factors

\section{Purpose}

Studies primary school science and mathematics teachers' views and attitudes toward integrating STEM in their teaching practices after participating in a professional development program in the KSA

Examines primary school science teachers' point of views on STEM education and its core interdisciplinary nature, as well as possible external and internal factors affecting STEM practices in the KSA

Investigates science teachers' perceptions about the integration of STEM pedagogies in their teaching, and competencies related to educational and economic issues in Oman

Addresses secondary school science and mathematics teachers' perception about implementation of newly formed STEM curricula, and the impact of teachers' gender, educational qualification, nationality, and teaching experience on their STEM perceptions in the KSA

Explores the effectiveness of laptop usage in enhancing undergraduate students learning at STEM disciplines, and the impact of private and public universities on the laptop usage for academic and non-academic purposes in the UAE

Examines secondary school science and mathematics teachers' pedagogical practices for delivering the newly adapted interdisciplinary STEM curricula in their classrooms in the KSA

Analyzes primary school mathematics and science teachers' understanding of, use of, and aspirations for delivering inquiry-based pedagogies in their STEM teaching in Qatar

Examines chemistry, physics, and biology course assessments at the secondary school level in Kuwait, based on educational taxonomies and cognitive, psychomotor, and emotional areas

Explores the factors, such as stereotypes, role of family, and nationality, which influence female undergraduate students' decisions and attitudes toward engaging in a STEM discipline in the UAE

Addresses the impact of stereotypes on society's view about STEM-related positions such as in mathematics, science and computing

Examines the impact of gender disparity on higher education students' perceptions of their STEM professors in the Middle East 
Table 3 (continued)

\begin{tabular}{lll}
\hline Authors & Thematic Focus & Scope \\
\hline Khan and Rodrigues, (2017) & Environmental factors & Family income \\
& & \\
Wang et al., (2020) & $\begin{array}{l}\text { Environmental factors, School-level } \\
\text { factors }\end{array}$ & Cultural and societal beliefs
\end{tabular}

Islam, (2017)

Islam, (2019)

Student-level factors, school-level factors,

\section{Purpose}

Investigates gender disparity issue in the low-income expatriate families living in the UAE, particularly exploring point of views on female STEM education and employment opportunities

Analyzes existing papers at the Middle East region, including GCC countries, to examine cultural and national barriers to stem education, barriers against female stem education and employment, as well as educational barriers such as poor scholarship and teaching, poor working environment for educators

STEM achievement, nationality

Interest in, attitude toward and perception about STEM
Social perceptions and prejudices

STEM attitudes
Analyzes existing papers in the Arab region, including GCC countries, to examine how social perception and prejudice determine gender in STEM employment

Analyzes existing papers in the Middle East region, including GCC countries, to examine how social perception and prejudice determine female issue related to higher education, STEM education, and career opportunities and research

Investigates the correlation among students' STEM performance and a number of cognitive variables such as high school grades as well as noncognitive variables such as attitudes and skill-related behaviors, in Qatar

Analyzes the existing papers on the relationship between citizenship status, STEM education, and expected labor market participation in GCC countries, taking into consideration student-level measures (e.g., TIMSS scores, nationality), and school-level measures (e.g., software availability, school achievement)

Examines secondary school students' interest in, attitude toward and perception about STEM learning in different contexts, in the UAE

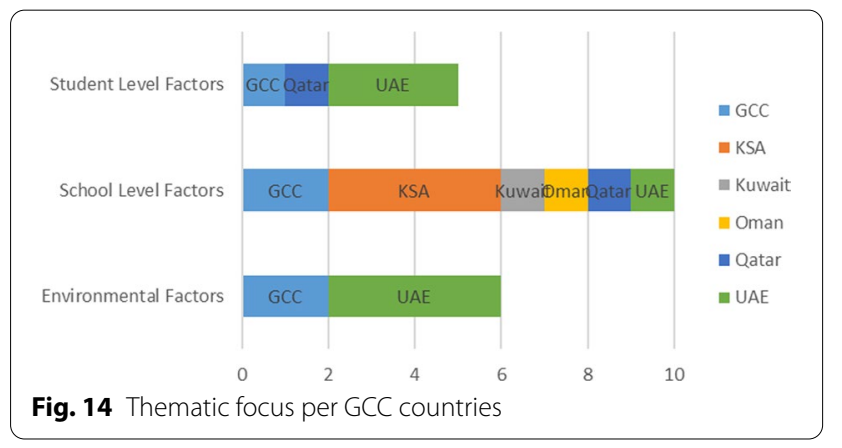

knowledge and labor market expectations of Gulf youth (Wiseman et al., 2016).

The present review highlights women's underrepresentation in secondary and tertiary STEM-related disciplines and careers (Chachashvili-Bolotin et al., 2016; OECD, 2006). Enrollment in tertiary education within the Arab region is high compared to other world regions, for there is even an imbalance in favor of women as in most of the Gulf States (Islam, 2017). However, graduate women who attempt to pursue a career or a postgraduate degree are often excluded based on their gender. Traditional and cultural norms 
governing Gulf societies determine the type of employment that is particularly suitable for women. A spillover effect of this includes institutional influences and gender stereotyping, which deter women from entering and remaining a job (DeBoer \& Ater Kranov, 2017; Pasha-Zaidi \& Afari, 2016).

Evidence also indicates the important role of the family and the significant effect of parental support in females' decisions to enroll in a STEM field, particularly in the Gulf region (Mahani \& Molki, 2011; Pasha-Zaidi \& Afari, 2016). The Gulf countries have invested significant funds in education in order to transition to a knowledge society. Nonetheless, there is a stark need for student enrollment and achievement in STEM fields of study in these countries. Students' interest in enrolling in STEM fields of study is rather low and so is their participation in STEM-oriented careers and interest in private sector employment (Wiseman et al., 2016).

Yet another gap-a methodological one-can be seen in the lack of a comprehensive framework, consistency or agreed upon structure that can be used by institutions study the cognitive and non-cognitive predictors of students' performance (Al-Sheeb et al., 2019). In addition, there is no protocol purposefully designed to observe STEM integration classes or structured interviews for STEM implementation (Madani, 2020). It is also clear that existing research in the region relies mostly on secondary data and has not examined in greater detail women's participation in STEM (Aswad et al., 2011). Consequently, this reflects on a lack of tailored and contextualized programs and policies (Aswad et al., 2011).

Equally interesting is the absence of studies that investigate potential enablers of student participation in STEM fields of study and eventual careers. The lack of research that identifies such enablers in the GCC context has caused missed opportunities that would have otherwise permitted a more informed investigation of students' and teachers' desire and interest in engaging with STEM. Finally, further research is suggested on various topics, including institutional barriers to STEM enrollment, the influence of high school education on students' aspirations, as well as the factors that influence the retention of women in STEM fields (Aswad et al., 2011).

Also missing in scholarship on STEM in the region are studies that try to offer insights based on comparative data analyses. Four of the six countries that make up the GCC-namely Bahrain, Kuwait, Qatar and the UAEare generally regarded as small city-states. Therefore, conducting comparative research will broaden the focus beyond a country's national borders and offer a very rich and robust perspective that helps to understand the focus, scope and complexity of STEM education within and between these countries.
Yet another gap characterizing STEM research in the GCC is the absence of longitudinal studies that look at how interest in and perceptions of STEM change over time. For instance, studies of this type will assist in better understanding variation in the developmental trajectories of students' interest, entry and persistence in STEM. In turn, this can boost the extent to which findings generalize to other societies with heterogeneous and predominantly immigrant student populations such as those of the GCC States.

\section{Discussion}

Useful as the research reviewed in the current study may be, and helpful as it is in providing some important insights into STEM in the context of the GCC, a number of missing elements stand out as requiring further study and analysis. Drawing on the findings of this study, certain key shortcomings were identified in the existing literature on STEM in the GCC. Combined, the studies reviewed pointed to salient gaps. First, women remain largely underrepresented, resulting in visible gender disparities. Second, GCC STEM research reveals some key methodological issues, including for example a demonstrable lack of comparative or longitudinal approaches. Third, there is a clear absence of research that explores enablers that may enhance student participation in STEM-related fields of study and careers. Incorporating these elements in future research will enhance the quality of research on STEM in the region. For example, a prevalent feature running through most of the research dealing with STEM in the six GCC countries is the disregard of well-established theoretical models such as the EVT and the SCCT. Using these two theories has the advantage of enlightening and guiding research, as well as providing background information for the topic under study.

STEM research in the GCC has explored the topic largely within the school setting. A major gap in this area of research is the neglect of how STEM is perceived by the larger community in the GCC societies. Prominent in this area is the crucial role that cultural factors play in unveiling how STEM is perceived by people in the local community. A representative example of these factors is the way stereotyping influences students' entry and persistence in STEM fields of study and careers. Another is the broader socio-cultural environment associated with how education in general-and STEM study in particular-is viewed within GCC societies.

Looking at teachers' attitudes and perceptions of STEM, research shows that teachers need proper training to design and teach the STEM curriculum efficiently (Aldahmash et al., 2019). Overall, most of the articles analyzed in this study stress the need to engage teachers in STEM professional development programs in order to 
improve their attitudes towards STEM and increase their interest and efficiency in teaching STEM disciplines. More relevant, STEM teaching and assessment methods seem to require professional development programs. Research has also shown that the choice of constructive teaching methods is positively related to teachers' attitudes towards science (Osborne et al., 2003). Therefore, it is crucial to develop effective STEM professional development programs that address teachers' professional requirements and provide the necessary tools a teacher can use when teaching STEM.

Finally, in terms of student-level factors, the articles analyzed in this review focus mainly on gender disparities and stereotypes. It is important for GCC countries to address how gender influences STEM education enrollment and achievement. In their study of the effect of gender on perceptions of mathematics and science instructors at the university level in the UAE, PashaZaidi and Afari (2016) note a significant cross-gender effect on students' perceptions. The authors recommend additional research on gender preferences in the Gulf region in order to address student recruitment in STEM disciplines.

Using cognitive and non-cognitive factors, another study tried to explain college students' persistence and academic success, examining students from the college of engineering at Qatar University (Al-Sheeb et al., 2019). The study concludes that non-cognitive factors are more important than cognitive factors in predicting students' academic performance. Another study by Wiseman et al. (2016) indicated a relationship between citizenship status, education and labor force participation in the GCC countries.

\section{Conclusion and suggestions}

This systematic review illuminates a number of features characterizing research on STEM education in the GCC. The demographic (year), geographic (country), methodological (methods) and study population characteristics (participants, level of education), and the thematic focus of these articles vary from one country to another. Nonetheless, they offer useful insights into the scope and complexity of research done on STEM education in the GCC area, in addition to the existing gaps, issues and problems within the research.

The present study sought to provide a systematic review of STEM-related research done in the Gulf region. The review of the selected paper highlights three main gaps associated with STEM. Consequently, in order to be relevant to policy-making, future studies should focus on addressing these identified gaps. This will contribute to human capacity building in the GCC countries and support the transition to a knowledge-based economy. The findings of this review stress the need for future research on institutional barriers to STEM enrollment, the influence of high school education on students' aspirations, as well as the factors that may influence the retention of women in STEM fields.

Aside from the present systematic review, a close examination of STEM-related research in general discloses multiple perspectives about STEM and STEM education (Xiao, \& Froyd, 2020). This current review has shown that cultural (stereotypes), contextual factors (role models and the family), school- and student-level factors act as barriers to students' participation in STEM fields in the GCC States. This is in line with international scholarship on STEM particularly that conducted in north Western countries. Much like this systematic review, available work in other international contexts has investigated STEM-related gaps, including the insufficient preparation of students (Ejiwale, 2013; Hunter, 2019; Watkins, \& Mazur, 2013) and poor or under preparation of STEM teachers (Nadelson et al., 2013; Rinke et al., 2016; Shernoff et al., 2017). Other research has explored lack of qualified STEM teachers (Blackley, \& Howell, 2015; Ejiwale, 2013; Garrett, 2008) and lack of professional development programs for STEM teachers (Brown \& Bogiages, 2019; Nadelson et al., 2013; Ring et al., 2017).

As the GCC countries have embraced a series of educational policy reforms, their educational systems stand to benefit from certain other key interventions to do with research. First, there is a need to fund and promote STEM-focused research projects and develop educational programs and curricula; this will help to inform classroom teaching and learning, and enrich learners' out-of-school experiences. Second, work on STEM disciplines should be expanded to encompass the various domains of STEM and related other STEM disciplines. At present, physics, chemistry, medicine do not appear to have attracted sufficient interest from GCC-based scholars.

\section{Limitations}

Though this review was undertaken rigorously, each systematic review is limited by its search procedure. In particular, although the three selected databases are international in scope, by applying the criteria of peerreviewed articles published in English, papers published in other languages were not included. This also applies to publications in other venues such as conference proceedings, books, grant proposals, and articles not published in journals that are indexed in those three databases. Future reviews may consider using a larger number of databases, publication types and more than one language in order to widen the scope of the review. 


\section{Appendix A}

\begin{tabular}{|c|c|c|c|c|c|c|c|c|}
\hline \# & $\begin{array}{l}\text { Authors and } \\
\text { affiliations }\end{array}$ & References & Year & Country & Participants & Level of education & Methods & Thematic focus \\
\hline 1 & $\begin{array}{l}\text { Aldahmash, A. H., } \\
\text { King Saud University, } \\
\text { KSA } \\
\text { Alamri, N., M., King } \\
\text { Saud University, KSA } \\
\text { Aljallal, M. A., The } \\
\text { Ministry of Educa- } \\
\text { tion, KSA }\end{array}$ & $\begin{array}{l}\text { Aldahmash, A. H., } \\
\text { Alamri, N., M., \& Aljal- } \\
\text { lal, M. A. (2019). Saudi } \\
\text { Arabian science and } \\
\text { mathematics teach- } \\
\text { ers'attitudes toward } \\
\text { integrating STEM in } \\
\text { teaching before and } \\
\text { after participating in } \\
\text { a professional devel- } \\
\text { opment program. } \\
\text { Cogent Education, } \\
6(1), 1-21 \text {. https://doi. } \\
\text { org/10.1080/23311 } \\
\text { 86X.2019.1580852 }\end{array}$ & 2019 & KSA & $\mathrm{K}-12$ teachers & Primary education & Quantitative & $\begin{array}{l}\text { School-level } \\
\text { factors }\end{array}$ \\
\hline 2 & $\begin{array}{l}\text { Alhashem, F., Gulf } \\
\text { University, Kuwait } \\
\text { Agha, N., Ministry of } \\
\text { Education, Kuwait }\end{array}$ & $\begin{array}{l}\text { Alhashem, F., \& Agha, } \\
\text { N. (2020). Analysis } \\
\text { based on the three } \\
\text { objective educational } \\
\text { domains for final } \\
\text { summative second- } \\
\text { ary examinations } \\
\text { of science subject } \\
\text { (chemistry, phys- } \\
\text { ics, and biology). } \\
\text { Education Research } \\
\text { International, https:// } \\
\text { doi.org/10.1155/ } \\
\text { 2020/8886126 }\end{array}$ & 2020 & Kuwait & Conceptual data & $\begin{array}{l}\text { Secondary educa- } \\
\text { tion }\end{array}$ & Qualitative & $\begin{array}{l}\text { School-level } \\
\text { factors }\end{array}$ \\
\hline 3 & $\begin{array}{l}\text { Al-Sheeb, B., Qatar } \\
\text { University, Qatar } \\
\text { Hamouda, A. M., } \\
\text { Qatar University, } \\
\text { Qatar } \\
\text { Abdella, G. M., Qatar } \\
\text { University, Qatar }\end{array}$ & $\begin{array}{l}\text { Al-Sheeb, B., } \\
\text { Hamouda, A. M., \& } \\
\text { Abdella, G. M. (2019). } \\
\text { Modeling of student } \\
\text { academic achieve- } \\
\text { ment in engineering } \\
\text { education using } \\
\text { cognitive and non- } \\
\text { cognitive factors. } \\
\text { Journal of Applied } \\
\text { Research in Higher } \\
\text { Education, } 11(2), \\
\text { 178-198. https://doi. } \\
\text { org/10.1108/JARHE- } \\
\text { 10-2017-0120 }\end{array}$ & 2019 & Qatar & $\begin{array}{l}\text { Undergraduate } \\
\text { students }\end{array}$ & Higher education & Quantitative & $\begin{array}{l}\text { Student-level } \\
\text { factors }\end{array}$ \\
\hline 4 & $\begin{array}{l}\text { Aswad, N. G., Masdar } \\
\text { Institute of Science } \\
\text { and Technology, UAE } \\
\text { Vidican, G., Masdar } \\
\text { Institute of Science } \\
\text { and Technology, UAE } \\
\text { Samulewicz, D., } \\
\text { Masdar Institute of } \\
\text { Science and Technol- } \\
\text { ogy, UAE }\end{array}$ & $\begin{array}{l}\text { Aswad, N. G., Vidican, } \\
\text { G., \& Samulewicz, D. } \\
\text { (2011). Creating a } \\
\text { knowledge-based } \\
\text { economy in the } \\
\text { United Arab Emir- } \\
\text { ates: realizing the } \\
\text { unfulfilled potential } \\
\text { of women in the } \\
\text { science, technology } \\
\text { and engineering } \\
\text { fields. European } \\
\text { Journal of Engineering } \\
\text { Education, 36(6), } \\
\text { 559-570. https://doi. } \\
\text { org/10.1080/03043 } \\
\text { 797.2011.624174 }\end{array}$ & 2011 & UAE & $\begin{array}{l}\text { Undergraduate } \\
\text { students }\end{array}$ & Higher education & Mixed & $\begin{array}{l}\text { Environmental } \\
\text { factors, student- } \\
\text { level factors }\end{array}$ \\
\hline
\end{tabular}




\begin{tabular}{|c|c|c|c|c|c|c|c|c|}
\hline \# & $\begin{array}{l}\text { Authors and } \\
\text { affiliations }\end{array}$ & References & Year & Country & Participants & Level of education & Methods & Thematic focus \\
\hline 5 & $\begin{array}{l}\text { Awwad, F., United } \\
\text { Arab Emirates } \\
\text { University, UAE } \\
\text { Ayesh, A., United } \\
\text { Arab Emirates } \\
\text { University, UAE }\end{array}$ & $\begin{array}{l}\text { Awwad, F., \& Ayesh, } \\
\text { A. (2013). Effective- } \\
\text { ness of laptop usage } \\
\text { in UAE university } \\
\text { undergraduate } \\
\text { teaching. Turkish } \\
\text { Online Journal of } \\
\text { Educational Technol- } \\
\text { ogy, 12(2), 77-88. } \\
\text { Retrieved from } \\
\text { http://0-search.proqu } \\
\text { est.com.mylibrary. } \\
\text { qu.edu.qa/scholarly- } \\
\text { journals/effectiven } \\
\text { ess-laptop-usage- } \\
\text { uae-university/docvi } \\
\text { ew/1509088680/ } \\
\text { se-2?accountid= } \\
\text { 13370 }\end{array}$ & 2013 & UAE & $\begin{array}{l}\text { Undergraduate } \\
\text { students }\end{array}$ & Higher education & Quantitative & $\begin{array}{l}\text { School-level } \\
\text { factors }\end{array}$ \\
\hline 6 & $\begin{array}{l}\text { Badri, M., Abu Dhabi } \\
\text { Education Council, } \\
\text { UAE } \\
\text { Alnuaimi, A., Abu } \\
\text { Dhabi Education } \\
\text { Council, UAE } \\
\text { Mohaidat, J., Abu } \\
\text { Dhabi Education } \\
\text { Council, UAE } \\
\text { Al Rashedi, A., Abu } \\
\text { Dhabi Education } \\
\text { Council, UAE } \\
\text { Yang, G., Abu Dhabi } \\
\text { Education Council, } \\
\text { UAE } \\
\text { Al Mazroui, K., UAE } \\
\text { University, UAE }\end{array}$ & $\begin{array}{l}\text { Badri, M., Alnuaimi, } \\
\text { A., Mohaidat, J., Al } \\
\text { Rashedi, A., Yang, } \\
\text { G., \& Al Mazroui, K. } \\
\text { (2016). My science } \\
\text { class and expected } \\
\text { career choices-a } \\
\text { structural equation } \\
\text { model of determi- } \\
\text { nants involving Abu } \\
\text { dhabi high school } \\
\text { students. Interna- } \\
\text { tional Journal of STEM } \\
\text { Education, 3(1), 1-21. } \\
\text { https://doi.org/10. } \\
\text { 1186/s40594-016- } \\
\text { 0045-0 }\end{array}$ & 2016 & UAE & K-12 students & $\begin{array}{l}\text { Secondary educa- } \\
\text { tion }\end{array}$ & Quantitative & $\begin{array}{l}\text { Student-level } \\
\text { factors }\end{array}$ \\
\hline 7 & $\begin{array}{l}\text { Elayyan, S. R., Sohar } \\
\text { University, Oman } \\
\text { Al-Shizawi, F., Min- } \\
\text { istry of Education, } \\
\text { Oman }\end{array}$ & $\begin{array}{l}\text { Elayyan, S. R., \& } \\
\text { Al-Shizawi, F. (2019). } \\
\text { Teachers'perceptions } \\
\text { of integrating STEM } \\
\text { in Omani schools. } \\
\text { Shanlax International } \\
\text { Journal of Education, } \\
\text { 8(1), 16-21. Retrieved } \\
\text { from http://0-search. } \\
\text { proquest.com.mylib } \\
\text { rary.qu.edu.qa/schol } \\
\text { arly-journals/teach } \\
\text { ers-perceptions-integ } \\
\text { rating-stem-omani/ } \\
\text { docview/23968 } \\
\text { 49350/se-2?accou } \\
\text { ntid=13370 }\end{array}$ & 2019 & Oman & K-12 teachers & $\begin{array}{l}\text { Secondary educa- } \\
\text { tion }\end{array}$ & Quantitative & $\begin{array}{l}\text { School-level } \\
\text { factors }\end{array}$ \\
\hline 8 & $\begin{array}{l}\text { El-Deghaidy, H., } \\
\text { American University } \\
\text { in Cairo, Egypt } \\
\text { Mansour, N., Ameri- } \\
\text { can University in } \\
\text { Cairo, Egypt } \\
\text { Alzaghibi, M., Minis- } \\
\text { try of Education, KSA } \\
\text { Alhammad, K., Minis- } \\
\text { try of Education, KSA }\end{array}$ & $\begin{array}{l}\text { El-Deghaidy, H., Man- } \\
\text { sour, N., Alzagibi, } \\
\text { M., \& Alhammad, K. } \\
\text { (2017). Context of } \\
\text { STEM integration in } \\
\text { schools: Views from } \\
\text { in-service science } \\
\text { teachers. EURASIA } \\
\text { Journal of Mathemat- } \\
\text { ics, Science \& Technol- } \\
\text { ogy Education, 13(6), } \\
\text { 2459-2484. Retrieved } \\
\text { from http://0-search. } \\
\text { proquest.com.mylib } \\
\text { rary.qu.edu.qa/schol } \\
\text { arly-journals/conte } \\
\text { xt-stem-integration- } \\
\text { schools-views-servi } \\
\text { ce/docview/19133 } \\
52573 / \text { se-2?accou } \\
\text { ntid=13370 }\end{array}$ & 2017 & KSA & K-12 teachers & Primary education & Qualitative & $\begin{array}{l}\text { School-level } \\
\text { factors }\end{array}$ \\
\hline
\end{tabular}




\begin{tabular}{|c|c|c|c|c|c|c|c|c|}
\hline \# & $\begin{array}{l}\text { Authors and } \\
\text { affiliations }\end{array}$ & References & Year & Country & Participants & Level of education & Methods & Thematic focus \\
\hline 9 & $\begin{array}{l}\text { Forgasz, H., Monash } \\
\text { University, Australia } \\
\text { Leder, G., Monash } \\
\text { University, Australia } \\
\text { Tan, H., Monash } \\
\text { University, Australia }\end{array}$ & $\begin{array}{l}\text { Forgasz, H., Leder, } \\
\text { G., \&Tan, H. (2014). } \\
\text { Public views on the } \\
\text { gendering of math- } \\
\text { ematics and related } \\
\text { careers: Interna- } \\
\text { tional comparisons. } \\
\text { Educational Studies in } \\
\text { Mathematics, 87(3), } \\
\text { 369-388. https://doi. } \\
\text { org/10.1007/s 10649- } \\
\text { 014-9550-6 }\end{array}$ & 2014 & UAE & Public & All levels & Quantitative & $\begin{array}{l}\text { Environmental } \\
\text { factors }\end{array}$ \\
\hline 10 & $\begin{array}{l}\text { Islam, S. I., Abdelaziz } \\
\text { University, KSA }\end{array}$ & $\begin{array}{l}\text { Islam, S. I. (2017). } \\
\text { Arab women in } \\
\text { science, technology, } \\
\text { engineering and } \\
\text { mathematics fields: } \\
\text { The way forward. } \\
\text { World Journal of } \\
\text { Education, } 7(6) \text {, } \\
\text { 12-20. Retrieved } \\
\text { from http://0-search. } \\
\text { proquest.com.mylib } \\
\text { rary.qu.edu.qa/ } \\
\text { scholarly-journals/ } \\
\text { arab-women-scien } \\
\text { ce-technology-engin } \\
\text { eering/docview/ } \\
\text { 2011270388/se-2? } \\
\text { accountid=13370 }\end{array}$ & 2017 & $\begin{array}{l}\text { KSA } \\
\text { Qatar } \\
\text { Oman } \\
\text { Bahrain } \\
\text { UAE }\end{array}$ & Conceptual data & All levels & Conceptual & $\begin{array}{l}\text { Environmental } \\
\text { factors }\end{array}$ \\
\hline 11 & $\begin{array}{l}\text { Islam, S. I., Abdelaziz } \\
\text { University, KSA }\end{array}$ & $\begin{array}{l}\text { Islam, S. I. (2019). } \\
\text { Science, technol- } \\
\text { ogy, engineering } \\
\text { and mathematics } \\
\text { (STEM): Liberating } \\
\text { women in the Middle } \\
\text { East. World Journal } \\
\text { of Education, 9(3), } \\
\text { 94-104. Retrieved } \\
\text { from http://0-search. } \\
\text { proquest.com.mylib } \\
\text { rary.qu.edu.qa/schol } \\
\text { arly-journals/scien } \\
\text { ce-technology-engin } \\
\text { eering-mathematics- } \\
\text { stem/docview/24611 } \\
\text { 23126/se-2?accou } \\
\text { ntid=13370 }\end{array}$ & 2019 & GCC & Conceptual data & All levels & Conceptual & $\begin{array}{l}\text { Environmental } \\
\text { factors }\end{array}$ \\
\hline 12 & $\begin{array}{l}\text { Khan, Z. R., University } \\
\text { of Wollongong in } \\
\text { Dubai, UAE } \\
\text { Rodrigues, G., } \\
\text { University of Wollon- } \\
\text { gong in Dubai, UAE }\end{array}$ & $\begin{array}{l}\text { Khan, Z. R., \& } \\
\text { Rodrigues, G. (2017). } \\
\text { STEM for girls from } \\
\text { low-income families: } \\
\text { Making dreams } \\
\text { come true. The } \\
\text { Journal of Developing } \\
\text { Areas, 51(2), 435-448. } \\
\text { Retrieved from } \\
\text { http://0-search.proqu } \\
\text { est.com.mylibrary. } \\
\text { qu.edu.qa/scholarly- } \\
\text { journals/stem-girls- } \\
\text { low-income-famil } \\
\text { ies-making-dreams- } \\
\text { come/docview/ } \\
\text { 1899787495/se-2? } \\
\text { accountid=13370 }\end{array}$ & 2017 & UAE & $\begin{array}{l}\text { K-12 students, under- } \\
\text { graduate students, } \\
\text { parents }\end{array}$ & $\begin{array}{l}\text { Higher education, } \\
\text { secondary educa- } \\
\text { tion }\end{array}$ & Mixed & $\begin{array}{l}\text { Environmental } \\
\text { factors }\end{array}$ \\
\hline
\end{tabular}




\begin{tabular}{|c|c|c|c|c|c|c|c|c|}
\hline \# & $\begin{array}{l}\text { Authors and } \\
\text { affiliations }\end{array}$ & References & Year & Country & Participants & Level of education & Methods & Thematic focus \\
\hline 13 & $\begin{array}{l}\text { Madani, R. A.., British } \\
\text { University in Dubai, } \\
\text { UAE } \\
\text { Forawi, S., British } \\
\text { University in Dubai, } \\
\text { UAE }\end{array}$ & $\begin{array}{l}\text { Madani, R. A., \& } \\
\text { Forawi, S. (2019). } \\
\text { Teacher percep- } \\
\text { tions of the new } \\
\text { mathematics and } \\
\text { science curriculum: } \\
\text { A step toward STEM } \\
\text { implementation } \\
\text { in Saudi Arabia. } \\
\text { Journal of Education } \\
\text { and Learning, 8(3), } \\
\text { 202-233. Retrieved } \\
\text { from http://0-search. } \\
\text { proquest.com.mylib } \\
\text { rary.qu.edu.qa/schol } \\
\text { arly-journals/teach } \\
\text { er-perceptions-new- } \\
\text { mathematics-scien } \\
\text { ce/docview/24611 } \\
\text { 25881/se-2?accou } \\
\text { ntid=13370 }\end{array}$ & 2019 & KSA & K-12 teachers & $\begin{array}{l}\text { Secondary educa- } \\
\text { tion }\end{array}$ & Mixed & $\begin{array}{l}\text { School-level } \\
\text { factors }\end{array}$ \\
\hline 14 & $\begin{array}{l}\text { Madani, R. A., British } \\
\text { University in Dubai, } \\
\text { UAE }\end{array}$ & $\begin{array}{l}\text { Madani, R. A. (2020). } \\
\text { Teaching challenges } \\
\text { and perceptions on } \\
\text { STEM implementa- } \\
\text { tion for schools } \\
\text { in Saudi Arabia. } \\
\text { European Journal } \\
\text { of STEM Education, } \\
\text { 5(1), 1-14. Retrieved } \\
\text { from http://0-search. } \\
\text { proquest.com.mylib } \\
\text { rary.qu.edu.qa/schol } \\
\text { arly-journals/teach } \\
\text { ing-challenges-perce } \\
\text { ptions-on-stem/ } \\
\text { docview/24590 } \\
\text { 02851/se-2?accou } \\
\text { ntid=13370 }\end{array}$ & 2020 & KSA & K-12 teachers & $\begin{array}{l}\text { Secondary educa- } \\
\text { tion }\end{array}$ & Qualitative & $\begin{array}{l}\text { School-level } \\
\text { factors }\end{array}$ \\
\hline 15 & $\begin{array}{l}\text { Murphy, C., Univer- } \\
\text { sity of Tasmania, } \\
\text { Australia } \\
\text { Abu-Tineh, A., Qatar } \\
\text { University, Qatar } \\
\text { Calder, N., University } \\
\text { of Waikato, New } \\
\text { Zealand } \\
\text { Mansour, N., Univer- } \\
\text { sity of Exeter, United } \\
\text { Kingdom }\end{array}$ & $\begin{array}{l}\text { Murphy, C., Abu- } \\
\text { Tineh, A., Calder, N., } \\
\text { \& Mansour, N. (2018). } \\
\text { Implementing dia- } \\
\text { logic inquiry in Qatari } \\
\text { mathematics and } \\
\text { science classrooms: } \\
\text { Challenges and prov- } \\
\text { ocations. Teachers } \\
\text { and Curriculum, 18(1), } \\
\text { 33-40. Retrieved } \\
\text { from http://0-search. } \\
\text { proquest.com.mylib } \\
\text { rary.qu.edu.qa/schol } \\
\text { arly-journals/imple } \\
\text { menting-dialogic- } \\
\text { inquiry-qatari-mathe } \\
\text { matics/docview/ } \\
\text { 2101885007/se-2? } \\
\text { accountid=13370 }\end{array}$ & 2018 & Qatar & K-12 teachers & Primary education & Qualitative & $\begin{array}{l}\text { School-level } \\
\text { factors }\end{array}$ \\
\hline
\end{tabular}




\begin{tabular}{|c|c|c|c|c|c|c|c|c|}
\hline \# & $\begin{array}{l}\text { Authors and } \\
\text { affiliations }\end{array}$ & References & Year & Country & Participants & Level of education & Methods & Thematic focus \\
\hline 16 & $\begin{array}{l}\text { Pasha-Zaidi, N., The } \\
\text { Petroleum Institute, } \\
\text { UAE } \\
\text { Afari, E.., The Petro- } \\
\text { leum Institute, UAE }\end{array}$ & $\begin{array}{l}\text { Pasha-Zaidi, N., } \\
\text { \& Afari, E. (2016). } \\
\text { Gender in STEM } \\
\text { education: An } \\
\text { exploratory study of } \\
\text { student perceptions } \\
\text { of math and science } \\
\text { instructors in the } \\
\text { United Arab Emirates. } \\
\text { International Journal } \\
\text { of Science and Math- } \\
\text { ematics Education, } \\
14(7), 1215-1231 . \\
\text { https://doi.org/10. } \\
1007 / \text { s10763-015- } \\
\text { 9656-z }\end{array}$ & 2016 & UAE & $\begin{array}{l}\text { Undergraduate } \\
\text { students }\end{array}$ & Higher education & Quantitative & $\begin{array}{l}\text { Environmental } \\
\text { factors, student- } \\
\text { level factors }\end{array}$ \\
\hline 17 & $\begin{array}{l}\text { Wang, D. R., Cornell } \\
\text { University, USA } \\
\text { Hajjar, D. P., Cornell } \\
\text { University, USA } \\
\text { Cole, C. L., Cornell } \\
\text { University, USA }\end{array}$ & $\begin{array}{l}\text { Wang, D. R., Hajjar, } \\
\text { D. P., \& Cole, C. L. } \\
\text { (2020). International } \\
\text { partnerships for the } \\
\text { development of } \\
\text { science, technology, } \\
\text { engineering, math- } \\
\text { ematics, and medical } \\
\text { education of Middle } \\
\text { Eastern women. } \\
\text { International Journal } \\
\text { of Higher Education, } \\
\text { 9(2), 1-15. Retrieved } \\
\text { from http://0-search. } \\
\text { proquest.com.mylib } \\
\text { rary.qu.edu.qa/schol } \\
\text { arly-journals/inter } \\
\text { national-partnershi } \\
\text { ps-development- } \\
\text { science/docview/ } \\
\text { 2396836408/se-2? } \\
\text { accountid=13370 }\end{array}$ & 2020 & GCC & Conceptual data & All levels & Conceptual & $\begin{array}{l}\text { Environmental } \\
\text { factors, school- } \\
\text { level factors }\end{array}$ \\
\hline 18 & $\begin{array}{l}\text { Wiseman, A. W., } \\
\text { Lehigh University, } \\
\text { Pennsylvania } \\
\text { Abdelfattah, F. A., } \\
\text { University of Dam- } \\
\text { mam, KSA } \\
\text { Almassaad, A., King } \\
\text { Saud University, KSA }\end{array}$ & $\begin{array}{l}\text { Wiseman, A. W., } \\
\text { Abdelfattah, F. A., \& } \\
\text { Almassaad, A. (2016). } \\
\text { The intersection of } \\
\text { citizenship status, } \\
\text { STEM education, } \\
\text { and expected labor } \\
\text { market participation } \\
\text { in Gulf Cooperation } \\
\text { Council Countries. } \\
\text { DOMES: Digest of Mid- } \\
\text { dle East Studies, 25(2), } \\
\text { 362-392. Retrieved } \\
\text { from https://doi.org/ } \\
\text { 10.1111/dome.12087 }\end{array}$ & 2016 & GCC & $\mathrm{K}-12$ students & Primary education & Quantitative & $\begin{array}{l}\text { Student-level fac- } \\
\text { tors, school-level } \\
\text { factors }\end{array}$ \\
\hline
\end{tabular}

\section{Abbreviations}

GCC: Gulf Cooperation Council; IES: International Association for the Evaluation of Educational Achievement; KSA: Kingdom of Saudi Arabia; OECD: Organisation for Economic Co-Operation and Development; PISA: Programme for International Student Assessment; PRISMA: Preferred Reporting Items for Systematic Reviews and Meta-Analyses; SCCT: Social Cognitive Career Theory; STEM: Science, Technology, Engineering, Mathematics; TIMSS: Trends in International Mathematics and Science Study; UAE: United Arab Emirates.

\section{Acknowledgements}

Not applicable.

\section{Authors' contributions}

The authors declare that each author has made a substantial contribution to this article, has approved the submitted version and has agreed to be personally accountable for the author's own contributions. In particular, FKF, ALS, NA and SU conducted the literature review, conducted the data analysis, and contributed to the development of the manuscript. ALS made edit, proof-read and polished the final version. FKF drafted the manuscript, continuously revised the versions and acted as the corresponding author. All authors read and approved the final manuscript.

\section{Funding}

This research is supported by the Qatar University (QU) Office of Research Support (ORS), under the Grant number QUCG-SESRI-20/21-1 for the project entitled "Barriers to Student Participation STEM Education in Qatar".

\section{Availability of data and materials}

All data used in this paper are publicly available repositories, including various electronic databases as described in the methodology section.

\section{Declarations}

Competing interests

The authors declare that they have no competing interests. 


\section{Author details}

${ }^{1}$ Core Curriculum Program, Deanship of General Studies, Qatar University, P.O. Box 2713, Doha, Qatar. Education Research Center, College of Education, Qatar University, Doha, Qatar. ${ }^{3}$ Social and Economic Survey Research Institute (SESRI) Qatar University, Doha, Qatar.

Received: 22 February 2021 Accepted: 15 December 2021 Published online: 03 January 2022

\section{References}

Abdel-Ahad, J. A., \& Tzannatos, Z. (2016). We have education, where are the jobs? Job creation and returns to education in the Arab world. Silatech Brief. Retrieved from https://silatech.org/wp-content/uploads/2018/12/ policy-brief_we-have-education-where-are-the-jobs.pdf.

Aldahmash, A. H., Alamri, N. M., \& Aljallal, M. A. (2019). Saudi Arabian science and mathematics teachers' attitudes toward integrating STEM in teaching before and after participating in a professional development program. Cogent Education, 6(1), 1-21. https://doi.org/10.1080/23311 86X.2019.1580852

Alhashem, F., \& Agha, N. (2020). Analysis based on the three objective educational domains for final summative secondary examinations of science subject (chemistry, physics, and biology). Education Research International. https://doi.org/10.1155/2020/8886126

Al-Heeti, A. G., \& Brock, C. (1997). Vocational education and development: key issues, with special reference to the Arab world. International Journal of Educational Development, 17(4), 373-389.

Al-Sheeb, B. A., Hamouda, A. M., \& Abdella, G. M. (2019). Modeling of student academic achievement in engineering education using cognitive and non-cognitive factors. Journal of Applied Research in Higher Education, 11(2), 178-198. https://doi.org/10.1108/JARHE-10-2017-0120

Aschbacher, P. R., Li, E., \& Roth, E. J. (2010). Is science me? High school students' identities, participation and aspirations in science, engineering, and medicine. Journal of Research in Science Teaching, 47(5), 564-582.

Asghar, A., Ellington, R., Rice, E., Johnson, F., \& Prime, G. M. (2012). Supporting STEM education in secondary science contexts. The Interdisciplinary Journal of Problem-Based Learning, 6(2), 85-125. https://doi.org/10.7771/ 1541-5015.1349

Aswad, N. G., Vidican, G., \& Samulewicz, D. (2011). Creating a knowledge-based economy in the United Arab Emirates: realising the unfulfilled potential of women in the science, technology and engineering fields. European Journal of Engineering Education, 36(6), 559-570. https://doi.org/10. 1080/03043797.2011.624174

Awwad, F., \& Ayesh, A. (2013). Effectiveness of laptop usage in UAE university undergraduate teaching. Turkish Online Journal of Educational Technology, 12(2), 77-88.

Badri, M., Alnuaimi, A., Mohaidat, J., Al Rashedi, A., Yang, G., \& Al Mazroui, K. (2016). My science class and expected career choices-a structural equation model of determinants involving Abu Dhabi high school students. International Journal of STEM Education, 3(1), 1-21. https://doi.org/10. 1186/s40594-016-0045-0

Bandura, A., Barbaranelli, C., Caprara, G. V., \& Pastorelli, C. (2001). Self-efficacy beliefs as shapers of children's aspirations and career trajectories. Child Development, 72, 187-206.

Bierhoff, H. (1996). A comparison of primary school textbooks in Britain, Germany, and Switzerland. Teaching Mathematics and Its Applications, 15(4), 141-160.

Birch, K. (2017). Innovation, regional development and the life sciences: beyond clusters. Routledge.

Blackley, S., \& Howell, J. (2015). A STEM narrative: 15 years in the making. Australian Journal of Teacher Education, 40(7), 102-112. https://doi.org/ 10.14221/ajte.2015v40n7.8

Börner, K., Scrivner, O., Gallant, M., Ma, S., Liu, X., Chewning, K., Wue, L., \& Evans, J. A. (2018). Skill discrepancies between research, education, and jobs reveal the critical need to supply soft skills for the data economy. Proceedings of the National Academy of Sciences, 115(50), 12630-12637. https://doi.org/10.1073/pnas.1804247115

Bradley, K. (2000). The incorporation of women into higher education: paradoxical outcomes? Sociology of Education, 1-18.
Breiner, J. M., Harkness, S. S., Johnson, C. C., \& Koehler, C. M. (2012). What is STEM? A discussion about conceptions of STEM in education and partnerships. School Science and Mathematics, 112(1), 3-11. https://doi. org/10.1111/j.1949-8594.2011.00109.x

Brown, J. (2012). The current status of STEM education research. Journal of STEM Education Innovations and Research, 13(5), 7-11.

Brown, R. E., \& Bogiages, C. A. (2019). Professional development through STEM integration: how early career math and science teachers respond to experiencing integrated STEM tasks. International Journal of Science and Mathematics Education, 17(1), 111-128. https://doi.org/10.1007/ s10763-017-9863-x

Brown, S. D., \& Lent, R. W. (1996). A social cognitive framework for career choice counseling. The Career Development Quarterly, 44(4), 354-366.

Burke, R. J., \& Mattis, M. C. (Eds.). (2007). Women and minorities in science, technology, engineering, and mathematics: upping the numbers. Edward Elgar Publishing.

Bybee, R. W. (2018). STEM education now more than ever. National Science Teachers Association.

Carlone, H. B., \& Johnson, A. (2007). Understanding the science experiences of successful women of color: science identity as an analytic lens. Journal of Research in Science Teaching, 44(8), 1187-1218.

Carter, R. (1989). Women in engineering: A good place to be? Macmillan International Higher Education.

Chachashvili-Bolotin, S., Milner-Bolotin, M., \& Lissitsa, S. (2016). Examination of factors predicting secondary students' interest in tertiary STEM education. International Journal of Science Education, 38(3), 366-390.

DeBoer, J., \& Ater-Kranov, A. (2017). Key factors in the tertiary educational trajectories of women in engineering: Trends and opportunities in Saudi Arabia, the GCC, and comparative national settings. Science and Technology in the Gulf States, 56-88

Deming, D. J., \& Noray, K. (2020). Earnings dynamics, changing job skills, and STEM careers. The Quarterly Journal of Economics, 135(4), 1965-2005. https://doi.org/10.1093/qje/qjaa021

DeWitt, J., \& Archer, L. (2015). Who aspires to a science career? A comparison of survey responses from primary and secondary school students. International Journal of Science Education, 37(13), 2170-2192. https://doi. org/10.1080/09500693.2015.1071899

Drury, B. J., Siy, J. O., \& Cheryan, S. (2011). When do female role models benefit women? The importance of differentiating recruitment from retention in STEM. Psychological Inquiry, 22, 265-269. https://doi.org/10.1080/ 1047840X.2011.620935

Durik, A. M., Hulleman, C. S., \& Harackiewics, J. M. (2015). One size fits some: instructional enhancements to promote interest. Interest in Mathematics and Science Learning, 1(1), 49-62. https://doi.org/10.3102/ 978-0-935302-42-4_3

Eccles, J. (1983). Female achievement patterns: attributions, expectancies, values, and choice. Journal of Social Issues, 1, 1-22.

Eccles, J. (2009). Who am I and what am I going to do with my life? Personal and collective identities as motivators of action. Educational Psychologist, 44(2), 78-89.

Eccles-Parsons, J. S., Meece, J. L., Adler, T. F., \& Kaczula, C. M. (1982). Sex differences in attributions and learned helplessness. Sex Roles, 8, 421-432.

Ejiwale, J. A. (2013). Barriers to successful implementation of STEM education. Journal of Education and Learning, 7(2), 63-74.

Elayyan, S. R., \& AI-Shizawi, F. (2019). Teachers' perceptions of integrating STEM in Omani schools. Shanlax International Journal of Education, 8(1), 16-21.

El-Deghaidy, H., Mansour, N., Alzaghibi, M., \& Alhammad, K. (2017). Context of STEM integration in schools: views from in-service science teachers. EURASIA Journal of Mathematics, Science \& Technology Education, 13(6), 2459-2484.

Elliott, J., Stankov, L., Lee, J., \& Beckmann, J. F. (2019). What did PISA and TIMSS ever do for us? The potential of large scale datasets for understanding and improving educational practice. Comparative Education, 55(1), 133-155. https://doi.org/10.1080/03050068.2018.1545386

English, L. D. (2017). Advancing elementary and middle school STEM education. International Journal of Science and Mathematics Education, 15(1) 5-24. https://doi.org/10.1007/s10763-017-9802-x

Fasano, U., \& Goyal, R. (2004). Emerging strains in GCC labor markets. International Monetary Fund.

Forgasz, H., Leder, G., \& Tan, H. (2014). Public views on the gendering of mathematics and related careers: international comparisons. Educational 
Studies in Mathematics, 87(3), 369-388. https://doi.org/10.1007/ s10649-014-9550-6

Freeman, S., Eddy, S. L., McDonough, M., Smith, M. K., Okoroafor, N., Jordt, H., \& Wenderoth, M. P. (2014). Active learning increases student performance in science, engineering, and mathematics. Proceedings of the National Academy of Sciences, 111 (23), 8410-8415.

Garrett, J. L. (2008). STEM: the 21 st century sputnik. Kappa Delta Pi Record, 44(4), 152-153. https://doi.org/10.1080/00228958.2008.10516514

Gatti, R., Morgandi, M., Grun, R., Brodmann, S., Angel-Urdinola, D., Moreno, J. M., Marotta, D., Schiffbauer, M., \& Lorenzo, E. M. (2013). Jobs for shared prosperity: time for action in the Middle East and North Africa. The World Bank. https://doi.org/10.1596/978-0-8213-9719-0

Gilmartin, S. K., Li, E., \& Aschbacher, P. (2006). The relationship between secondary students' interest in physical science or engineering, science class experiences, and family contexts: variations by gender and race/ethnicity. Journal of Women and Minorities in Science and Engineering, 12(2-3), 179-207.

Gough, D., Oliver, S., \& Thomas, J. (2012). Introducing systematic reviews. In D. Gough, S. Oliver, \& J. Thomas (Eds.), An introduction to systematic reviews (pp. 1-16). Sage.

Greenwood, C., Harrison, M., \& Vignoles, A. (2011). The labour market value of STEM qualifications and occupations. Royal Academy of Engineering.

Han, S. W. (2016). National education systems and gender gaps in STEM occupational expectations. International Journal of Educational Development, 49, 175-187.

Harden, A., \& Gough, D. (2012). Quality and relevance appraisal. In D. Gough, S. Oliver, \& J. Thomas (Eds.), An introduction to systematic reviews (pp. 153-178). Sage.

Herbert, J., \& Stipek, D. (2005). The emergence of gender differences in children's perceptions of their academic competence. Journal of Applied Developmental Psychology, 26(3), 276-295.

Herrmann, S. D., Adelman, R. M., Bodford, J. E., Graudejus, O., Okun, M. A., \& Kwan, V. S. (2016). The effects of a female role model on academic performance and persistence of women in STEM courses. Basic and Applied Social Psychology, 38(5), 258-268. https://doi.org/10.1080/01973 533.2016.1209757

Holmlund, T. D., Lesseig, K., \& Slavit, D. (2018). Making sense of "STEM education" in K-12 contexts. International Journal of STEM Education, 5(1), 1-18. https://doi.org/10.1186/s40594-018-0127-2

Hunter, A. B. (2019). Why undergraduates leave STEM majors: changes over the last two decades. In H. Thiry, T. J. Weston, R. P. Harper, D. G. Holland, A. K. Koch, B. M. Drake, A. Hunter, \& E. Seymour (Eds.), Talking about leaving revisited: persistence, relocation, and loss in undergraduate stem education (pp. 87-114). Springer.

Hvidt, M. (2013). Economic diversification in GCC countries: past record and future trends. Research paper, Kuwait Programme on Development, Governance and Globalisation in the Gulf States. Retrieved from http:// www.lse.ac.uk/middleEastCentre/kuwait/documents/Economic-diver sification-in-the-GCC-countries.pdf.

Islam, S. I. (2017). Arab women in science, technology, engineering and mathematics fields: the way forward. World Journal of Education, 7(6), 12-20.

Islam, S. I. (2019). Science, technology, engineering and mathematics (STEM): liberating women in the Middle East. World Journal of Education, 9(3), 94-104.

Jenkins, E. W., \& Nelson, N. W. (2005). Important but not for me: students' attitudes towards secondary school science in England. Research in Science \& Technological Education, 23(1), 41-57.

Jones, M. G., Howe, A., \& Rua, M. J. (2000). Gender differences in students' experiences, interests, and attitudes toward science and scientists. Science Education, 84(2), 180-192.

Keeves, J., \& Kotte, D. (1992). Disparities between the sexes in science education: 1970-84. In J. Keeves (Ed.), The IEA study of science III. Pergamon.

Khan, Z. R., \& Rodrigues, G. (2017). STEM for girls from low-income families: making dreams come true. The Journal of Developing Areas, 51(2), 435-448.

Kim, M., \& Dopico, E. (2016). Science education through informal education. Cultural Studies of Science Education, 11, 1-7. https://doi.org/10.1007/ s1 1422-014-9639-3

Krapp, A., \& Prenzel, M. (2011). Research on interest in science: theories, methods, and findings. International Journal of Science Education, 33, 27-50. https://doi.org/10.1080/09500693.2010.518645
Kropf, A., \& Newbury-Smith, T. C. (2016). Wasta as a form of social capital? An institutional perspective. In M. A. Ramady (Ed.), The political economy of Wasta: use and abuse of social capital networking (pp. 3-21). Springer. https://doi.org/10.1007/978-3-319-22201-1_1

Lee, M. H., Chai, C. S., \& Hong, H. Y. (2019). STEM education in Asia Pacific: challenges and development. Asia-Pacific Education Researcher, 28(1), 1-4. https://doi.org/10.1007/s40299-018-0424-z

Lent, R. W., Brown, S. D., \& Hackett, G. (1994). Toward a unifying social cognitive theory of career and academic interest, choice, and performance. Journal of Vocational Behavior, 45(1), 79-122.

Lent, R. W., Brown, S. D., \& Hackett, G. (1996). Career development from a social cognitive perspective. Career Choice and Development, 3, 373-421.

Lent, R. W., Brown, S. D., \& Hackett, G. (2002). Social cognitive career theory. Career Choice and Development, 4, 255-311.

León, J., Núñez, J. L., \& Liew, J. (2015). Self-determination and STEM education: effects of autonomy, motivation, and self-regulated learning on high school math achievement. Learning and Individual Differences, 43, 156-163.

Li, Y., Schoenfeld, A. H., disessa, A. A., Graesser, A. C., Benson, L. C., English, L. D., \& Duschl, R. A. (2019). Design and design thinking in STEM education. Journal for STEM Education Research, 2, 93-104. https://doi.org/10.1007/ s41979-019-00020-z

Li, Y., Wang, K., Xiao, Y., \& Froyd, J. E. (2020). Research and trends in STEM education: a systematic review of journal publications. International Journal of STEM Education, 7(1), 1-16. https://doi.org/10.1186/s40594-020-00207-6

Liberati, A., Altman, D. G., Tetzlaff, J., Mulrow, C., Gøtzsche, P. C., Ioannidis, J. P., et al. (2009). The PRISMA statement for reporting systematic reviews and meta-analyses of studies that evaluate health care interventions: explanation and elaboration. Journal of Clinical Epidemiology, 62, 1-34. https://doi.org/10.1016/j.jclinepi.2009.06.006

Madani, R. A. (2020). Teaching challenges and perceptions on STEM implementation for schools in Saudi Arabia. European Journal of STEM Education, 5(1), 1-14.

Madani, R. A., \& Forawi, S. (2019). Teacher perceptions of the new mathematics and science curriculum: a step toward STEM implementation in Saudi Arabia. Journal of Education and Learning, 8(3), 202-233.

Mahani, S., \& Molki, A. (2011). Factors influencing female Emirati students' decision to study engineering. Global Journal of Engineering Education, 13(1), 26-31.

Malecki, E. J., \& Ewers, M. C. (2007). Labor migration to world cities: with a research agenda for the Arab Gulf. Progress in Human Geography, 31 , 467-484. https://doi.org/10.1177/0309132507079501

Martin, M.O., Mullis, I.V.S., Foy, P., \& Stanco, G.M. (2012). TIMSS 2011 international results in science. TIMSS \& PIRLS International Study Center, Boston College. Retrieved from https://timssandpirls.bc.edu/timss2011/downl oads/T11_IR_Science_FullBook.pdf.

Martin, M. O., Mullis, I. V.S., Foy, P, \& Hooper, M. (2016). TIMSS 2015 international results in science. TIMSS \& PIRLS International Study Center, Boston College. Retrieved from http://timss2015.org/wp-content/uploads/fileb ase/full\%20pdfs/T15-International-Results-in-Science.pdf.

Martín-Páez, T., Aguilera, D., Perales-Palacios, F. J., \& Vílchez-González, J. M. (2019). What are we talking about when we talk about STEM education? A review of literature. Science Education, 103(4), 799-822. https:// doi.org/10.1002/sce.21522

McGunagle, D., \& Zizka, L. (2020). Employability skills for 21 st-century STEM students: the employers' perspective. Higher Education, Skills and WorkBased Learning.

McHugh, M. L. (2012). Interrater reliability: the kappa statistic. Biochemia Medica, 22(3), 276-282.

Miller-Idriss, C., \& Hanauer, E. (2011). Transnational higher education: offshore campuses in the Middle East. Comparative Education, 47(2), 181-207. https://doi.org/10.1080/03050068.2011.553935

Mizell, S., \& Brown, S. (2016). The current status of STEM education research 2013-2015. Journal of STEM Education: Innovations and Research, 17(4), 52.

Mohamed, M., \& Morris, P. (2021). Buying, selling and outsourcing educational reform: the Global Education Industry and 'policy borrowing' in the Gulf. Compare A Journal of Comparative and International Education, 51(2), 181-201. https://doi.org/10.1080/03057925.2019.1607255

Moher, D., Liberati, A., Tetzlaff, J., \& Altman, D. G. (2009). Preferred reporting items for systematic reviews and meta-analyses: the PRISMA Statement. 
PLOS Medicine, 6(7), e1000097. https://doi.org/10.1371/journal.pmed. 1000097

Møller, A. M., \& Myles, P. S. (2016). What makes a good systematic review and meta-analysis? BJA British Journal of Anaesthesia, 117(4), 428-430. https://doi.org/10.1093/bja/aew264

Momani, B. (2017). Entrepreneurship: An engine for job creation and inclusive growth in the Arab world. Brookings Institution. Retrieved from https:// www.brookings.edu/research/entrepreneurship-an-engine-for-jobcreation-andinclusivegrowth-in-the-arab-world/. Accessed 2019/07/03

Morgan, C. (2018). The spectacle of global tests in the Arabian Gulf: a comparison of Qatar and the United Arab Emirates. Comparative Education, 54(3), 285-308.

Morrison, J., \& Bartlett, B. (2009). STEM as a curriculum: an experimental approach. Retrieved from http://www.lab-aids.com/docs/stem/EdWee kArticleSTEM.pdf.

Mullis, I.V.S., Martin, M.O., Foy, P., and Arora, A. (2012). The TIMSS 2011 international results in mathematics. TIMSS \& PIRLS International Study Center, Boston College. Retrieved from https://timssandpirls.bc.edu/timss2011/ downloads/T11_IR_Mathematics_FullBook.pdf.

Mullis, I. V.S., Martin, M. O, Foy, P, \& Hooper, M. (2016). TIMSS 2015 international results in mathematics. TIMSS \& PIRLS International Study Center, Boston College. Retrieved from http://timss2015.org/wp-content/uploads/fileb ase/full\%20pdfs/T15-International-Results-in-Mathematics.pdf.

Mullis, Ina V.S., Martin, Michael O., Foy, Pierre, Kelly, Dana L., Fishbein, Bethany (2020). TIMSS 2019 international results in mathematics and science. TIMSS \& PIRLS International Study Center, Boston College. Retrieved from https://www.iea.nl/sites/default/files/2020-12/TIMSS\%202019-Inter national-Results-in-Mathematics-and-Science.pdf.

Murphy, C., Abu-Tineh, A., Calder, N., \& Mansour, N. (2018). Implementing dialogic inquiry in Qatari mathematics and science classrooms: challenges and provocations. Teachers and Curriculum, 18(1), 33-40.

Murphy, S., MacDonald, A., Danaia, L., \& Wang, C. (2019). An analysis of Australian STEM education strategies. Policy Futures in Education, 17(2), 122-139.

Nadelson, L. S., Callahan, J., Pyke, P., Hay, A., Dance, M., \& Pfiester, J. (2013). Teacher STEM perception and preparation: inquiry-based STEM professional development for elementary teachers. The Journal of Educational Research, 106(2), 157-168. https://doi.org/10.1080/00220671.2012. 667014

National Academies of Sciences, Engineering, and Medicine (NASEM). (2018). Graduate STEM education for the 21st century. National Academies Press.

Nicholas, D., Watkinson, A., Jamali, H. R., Herman, E., Tenopir, C., Volentine, R., \& Levine, K. (2015). Peer review: still king in the digital age. Learned Publishing, 28(1), 15-21. https://doi.org/10.1087/20150104

Nóvoa, A., \& Yariv-Mashal, T. (2003). Comparative research in education: a mode of governance or a historical journey?". Comparative Education, 39(4), 423-438.

Organisation for Economic Co-Operation and Development (OECD) (2006) Women in scientific careers: Unleashing the Potential. OECD. Retrieved from http://www.oecd.org/science/sci-tech/womeninscientificcareersu nleashingthepotential.htm.

Organisation for Economic Co-Operation and Development (OECD) (2014). PISA 2012 results in focus: What 15 year olds know and what they can do with what they know. Retrieved from http://www.oecd.org/pisa/keyfi ndings/pisa-2012-results-overview.pdf.

Organisation for Economic Co-Operation and Development (OECD) (2016). PISA 2015 Results in Focus. Retrieved from http://www.oecd.org/pisa/ pisa-2015-results-in-focus.pdf.

Organisation for Economic Co-Operation and Development (OECD) (2018). Qatar: Student performance (PISA 2018). Retrieved from https://gpsed ucation.oecd.org/CountryProfile?primaryCountry $=$ QAT\&treshold $=10 \&$ topic $=$ PI.

Osborne, J., Simon, S., \& Collins, S. (2003). Attitudes towards science: a review of the literature and its implications. International Journal of Science Education, 25(9), 1049-1079. https://doi.org/10.1080/095006903200003 2199

Park, M., Dimitrov, D. M., Patterson, L. G., \& Park, D. (2017). Early childhood teachers' beliefs about readiness for teaching science, technology, engineering, and mathematics. Journal of Early Childhood Research, 15, 275-291. https://doi.org/10.1177/1476718X15614040
Pasha-Zaidi, N., \& Afari, E. (2016). Gender in STEM education: an exploratory study of student perceptions of math and science instructors in the United Arab Emirates. International Journal of Science and Mathematics Education, 14(7), 1215-1231. https://doi.org/10.1007/s10763-015-9656-z

Phipps, A. (2002). Engineering women: the gendering of professional identities. International Journal of Engineering Education, 18(4), 409-414.

Powell, J. J. W. (2012). Small state, large world, global university: comparing ascendant national universities in Luxemburg and Qatar. Current Issues in Comparative Education, 15(1), 100-113.

Preston, A., \& Whitehouse, G. (2004). Gender differences in occupation of employment within Australia. Working Paper No. 36. Perth, Australia: WEPAU, Curtin University of Technology. Retrieved from Microsoft Word-WEPAU WP-36 Sept 2004.doc (curtin.edu.au)

Ramirez, F. O., Luo, X., Schofer, E., \& Meyer, J. W. (2006). Student achievement and national economic growth. American Journal of Education, 113(1), $1-30$.

Reys, B. J., Reys, R. E., \& Chavez, O. (2004). Why mathematics textbooks matter. Educational Leadership, 5(61), 61-66.

Ring, E. A., Dare, E. A., Crotty, E. A., \& Roehrig, G. H. (2017). The evolution of teacher conceptions of STEM education throughout an intensive professional development experience. Journal of Science Teacher Education, 28(5), 444-467. https://doi.org/10.1080/1046560X.2017.1356671

Rinke, C. R., Gladstone-Brown, W., Kinlaw, C. R., \& Cappiello, J. (2016). Characterizing STEM teacher education: affordances and constraints of explicit STEM preparation for elementary teachers. School Science and Mathematics, 116(6), 300-309. https://doi.org/10.1111/ssm.12185

Rodeiro, C. L. V. (2007). A level subject choice in England: patterns of uptake and factors affecting subject preferences. University of Cambridge, Local Examinations Syndicate.

Said, Z. (2016). Science education reform in Qatar: progress and challenges. Eurasia Journal of Mathematics, Science and Technology Education, 12(8), 2253-2265.

Schreiner, C., \& Sjøberg, S. (2007). Sowing the seeds of ROSE: background, rationale, questionnaire development and data collection for ROSE (The Relevance of Science Education): a comparative study of students views of science and science education. Acta Didactica, 4, 1-120.

Sellami, A. L. (2019). Parental influence on student educational expectations: results from the 2012 Qatar Education Study. International Journal of Higher Education, 8(4), 189-201. https://doi.org/10.5430/ijhe.v8n4p189

Shernoff, D. J., Sinha, S., Bressler, D. M., \& Ginsburg, L. (2017). Assessing teacher education and professional development needs for the implementation of integrated approaches to STEM education. International Journal of STEM Education, 4(1), 1-16.

Simpkins, S. D., Davis-Kean, P. E., \& Eccles, J. S. (2005). Parents' socializing behavior and children's participation in math, science, and computer out-of-school activities. Applied Developmental Science, 9(1), 14-30.

Steiner-Khamsi, G. (2003). The politics of league tables. JSSE-Journal of Social Science Education, 2(1), 1-10.

Stout, J. G., Dasgupta, N., Hunsinger, M., \& McManus, M. (2011). STEMing the tide: Using ingroup experts to inoculate women's self-concept and professional goals in science, technology, engineering, and mathematics (STEM). Journal of Personality and Social Psychology, 100, 255-270. https://doi.org/10.1037/a0021385

Struyf, A., De Loof, H., Boeve-de Pauw, J., \& Van Petegem, P. (2019). Students' engagement in different STEM learning environments: integrated STEM education as promising practice? International Journal of Science Education, 41(10), 1387-1407. https://doi.org/10.1080/09500693.2019. 1607983

Su, R., Rounds, J., \& Armstrong, P. I. (2009). Men and things, women and people: a meta-analysis of sex differences in interests. Psychological Bulletin, 135(6), 859

Tai, R. H., Liu, C. Q., Maltese, A. V., \& Fan, X. (2006). Planning early for careers in science. Life Science, 312, 1143-1144.

Van den Hurk, A., Meelissen, M., \& Van Langen, A. (2019). Interventions in education to prevent STEM pipeline leakage. International Journal of Science Education, 41(2), 150-164. https://doi.org/10.1080/09500693. 2018.1540897

Van Laar, E., Van Deursen, A. J., Van Dijk, J. A., \& De Haan, J. (2017). The relation between 21 st-century skills and digital skills: a systematic literature review. Computers in Human Behavior, 72, 577-588. https://doi.org/10. 1016/j.chb.2017.03.010 
Wang, D. R., Hajjar, D. P., \& Cole, C. L. (2020). International partnerships for the development of science, technology, engineering, mathematics, and medical education of Middle Eastern women. International Journal of Higher Education, 9(2), 1-15.

Wang, H. H., Moore, T. J., Roehrig, G. H., \& Park, M. S. (2011). STEM integration: teacher perceptions and practice. Journal of Pre-College Engineering Education Research, 1(2), 1-13. https://doi.org/10.5703/1288284314636

Watkins, J., \& Mazur, E. (2013). Retaining students in science, technology, engineering, and mathematics (STEM) majors. Journal of College Science Teaching, 42(5), 36-41.

Wiseman, A. W., Abdelfattah, F. A., \& Almassaad, A. (2016). The intersection of citizenship status, STEM education, and expected labor market participation in gulf cooperation council countries. DOMES Digest of Middle East Studies, 25(2), 362-392. https://doi.org/10.1111/dome.12087

World Bank. (2008). The road not travelled: education reform in the Middle East and North Africa. World Bank. Retrieved from https://www.web.world bank.org/archive/website01033/WEB/IMAGES/EDU_flag.pdf.

Xu, M., Williams, P. J., Gu, J., \& Zhang, H. (2019). Hotspots and trends of technology education in the International Journal of Technology and Design Education: 2000-2018. International Journal of Technology and Design Education. https://doi.org/10.1007/s10798-019-09508-6

\section{Publisher's Note}

Springer Nature remains neutral with regard to jurisdictional claims in published maps and institutional affiliations.

\section{Submit your manuscript to a SpringerOpen ${ }^{\circ}$ journal and benefit from:}

- Convenient online submission

- Rigorous peer review

- Open access: articles freely available online

- High visibility within the field

- Retaining the copyright to your article

Submit your next manuscript at $\boldsymbol{\nabla}$ springeropen.com 